\title{
Role of dendritic cell maturity/costimulation for generation, homeostasis, and suppressive activity of regulatory $\top$ cells
}

\section{Katrien Pletinckx, Anja Döhler, Vladimir Pavlovic and Manfred B. Lutz*}

Institute of Virology and Immunobiology, University of Wuerzburg, Wuerzburg, Germany

Edited by:

Kendall A. Smith, Weill Medical

College of Cornell University, USA

\section{Reviewed by:}

Kendall A. Smith, Weill Medical

College of Cornell University, USA

Heather M. Wilson, University of

Aberdeen, UK

Andrew Mark Jackson, University of

Nottingham, UK

*Correspondence:

Manfred B. Lutz, Institute of Virology and Immunobiology, University of

Wuerzburg, Wuerzburg 97078,

Germany.

e-mail:m.lutz@vim.uni-wuerzburg.de
Tolerogenicity of dendritic cells (DCs) has initially been attributed exclusively to immature/resting stages, while mature/activated DCs were considered strictly immunogenic. Later, all different subsets among the myeloid/conventional DCs and plasmacytoid DCs have been shown to bear tolerogenic potential, so that tolerogenicity could not be attributed to a specific subset. Immunosuppressive treatments of immature DC subsets could prevent re-programming into mature DCs or upregulated inhibitory surface markers or cytokines. Furthermore, the different T cell tolerance mechanisms anergy, deletion, immune deviation, and suppression require different quantities and qualities of costimulation by DCs. Since expansion of regulatory T cells (Tregs) has been shown to be promoted best by fully mature DCs the role of CD80/B7-1 and CD86/B7-2 as major costimulatory molecules for Treg biology is under debate. In this review, we discuss the role of these and other costimulatory molecules on myeloid DCs and their ligands CD28 and CD152/CTLA-4 on Tregs for peripheral conversion from naive $\mathrm{CD}^{+}{ }^{+} \mathrm{T}$ cells into the major subsets of Foxp3 ${ }^{+}$Tregs and Foxp3- $\mathrm{IL}_{-10^{+}}$regulatory type-1 $\mathrm{T}$ cells (Tr1) or Tr1-like cells and their role for peripheral maintenance in the steady state and after activation.

Keywords: regulatory T cells, Foxp3, IL-10, dendritic cells, costimulation

\section{SUBSETS OF Tregs}

Regulatory $\mathrm{T}$ cells can be generated in the thymus and are released as so-called natural regulatory $\mathrm{T}$ cells (nTregs) or by extrathymic induction from naive $\mathrm{T}$ cells (iTregs) in secondary lymphoid organs (Horwitz et al., 2008; Sakaguchi et al., 2008; Yamazaki and Steinman, 2009). Several Treg subsets or functional states, depending on their anatomical origin or mode of generation, have been described (Sakaguchi et al., 2008) but a common signature or distinct sublineages may not exist (Feuerer et al., 2010). Two major subtypes of iTregs can be distinguished on the basis of their Foxp3 expression. Many authors refer only to the Foxp $3^{+}$subtypes as iTregs, while the Foxp $3^{-}$IL- $10^{+} \mathrm{T}$ cells are mostly named $\operatorname{Tr} 1$ (T regulatory type-1) or Tr1-like cells (Figure 1). Of note, most activated Tregs seem to release IL-10, independent of their Foxp3 expression (Figure 1). Since these Treg subsets have been in focus the last years, there is ample information about their interaction with DCs and this will be discussed here. In contrast, the less well investigated IL- $35^{+}$Tregs and TGF- $\beta$-producing Th3 or CD $8^{+}$ Tregs are reviewed elsewhere (Filaci and Suciu-Foca, 2002; Wang, 2008; Bettini and Vignali, 2009; Weiner et al., 2011). Since the generation of nTregs in the thymus seems not to depend on DCs but B7 costimulation on medullary epithelial cells and other APCs, we also refer to other reviews (Kyewski and Klein, 2006; Ohkura and Sakaguchi, 2010).

The best studied costimulatory molecules are CD80 (B7-1) and CD86 (B7-2). Both B7 molecules are the ligands of CD28 and

Abbreviations: APC, Antigen-presenting cells; DC, dendritic cell; iTreg, induced regulatory T cells; $\mathrm{nTreg}$, natural regulatory $\mathrm{T}$ cells; $\mathrm{Tr} 1, \mathrm{~T}$ regulatory type- $1 ; \mathrm{Th} 1, \mathrm{~T}$ helper 1; Th2, T helper 2; Th17, T helper 17.
CTLA-4 receptors on T cells (Lenschow et al., 1993). Whereas signaling by B7/CD28 pathway is crucial for enhancing $\mathrm{T}$ cell activation and survival, signaling by B7/CTLA- 4 mainly regulates inhibitory T cell responses (Sansom and Walker, 2006). Moreover, selectivity for CD28 to CD86 and CTLA-4 to CD80 interactions may have to be considered due to stoichiometric and affinity measurements in vitro (Collins et al., 2002).

\section{ROLE OF COSTIMULATION FOR THE GENERATION OF Tr1 CELLS} MOLECULAR FACTORS DRIVING IL-10 IN T CELLS

Initial reports defined Tr 1 cells as IL-10 producing $\mathrm{T}$ cells which developed from naive $\mathrm{T}$ cells and acquired suppressive activity in the presence of IL-10. They adapted a particular cytokine expression profile distinct from Th1 or Th2 effector T cells (Groux et al., 1997). However, ever since, many IL-10 producing Tregs have been described that could be induced under various experimental conditions (Table 1) and as reviewed in Hawrylowicz and O'Garra (2005), Roncarolo et al. (2006). Interestingly, high production of IL-10 and acquisition of regulatory function can also occur as a result of chronic stimulation of differentiated Thelper cells thereby gradually losing production of effector cytokines such as IFN$\gamma$ or IL-4 (O'Garra et al., 2004). The question remains whether all Foxp3 ${ }^{-}$IL- $10^{+}$iTregs cells that are either derived from naive $\mathrm{T}$ cell precursors $(\operatorname{Tr} 1)$ or from chronically stimulated effector $\mathrm{T}$ cells (Tr1-like) develop via similar IL-10- and costimulation-dependent signaling mechanisms. To date this remains unclear. However, for Th1-like cells common signaling pathways have been reported.

Saraiva et al. identified the mitogen-activated protein kinases Erk1 and Erk2 along with strong T cell receptor (TCR) triggering 


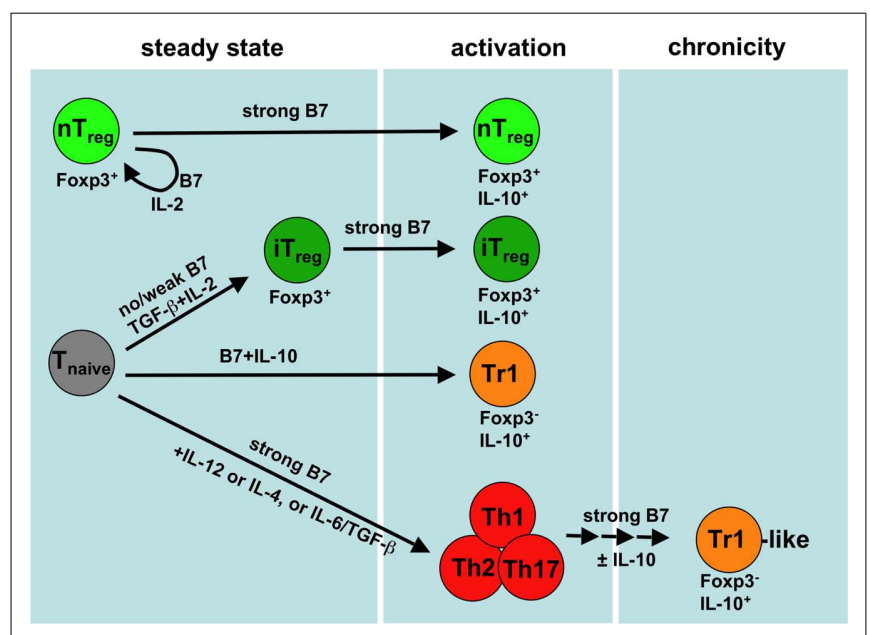

FIGURE 1 | Generation and maintenance of different Treg subsets and their costimulation requirements. During the steady state thymus derived Foxp $3^{+}$nTregs require IL-2 and B7 (CD80/CD86) costimulation to persist. The conversion of iTregs from naive T cells into the Foxp $3^{+}$subtype prefers the absence of B7 molecules but requires the presence of TGF- $\beta$ and IL-2. Strong B7 costimulation favors the activation of both Foxp3 ${ }^{+}$ nTregs and Foxp3+ iTregs such as provided by mature DCs. Generation of $\operatorname{Tr} 1$ cells from naive $T$ cells requires the presence of costimulation and IL-10. The appearance of Tr1-like cells is preceded by immunogenic Th1 (by IL-12), Th2 (by IL-4), or Th17 (by TGF- $\beta /$ IL-6) induction and subsequent short interval restimulations under the same immunogenic conditions that will result in a loss of the Th phenotype and a gain of IL-10 production capacity. Of note, all events indicated by arrows require TCR signals in addition.

and activation of the respective signal transducer and activator of transcription (STAT) as a common signaling pathway for the production of IL-10 by Th1, Th2, or Th17 effector T cells (Saraiva et al., 2009; Saraiva and O'Garra, 2010). Motomura et al. (2011) further supported the concept of a common signaling cascade for the appearance of IL-10 by effector T cells by identifying the central transcription factor E4 promoter-binding protein 4 (E4BP4), also known as NFIL3, essential for the regulation of both the IL-13 and IL-10 expression in chronically stimulated Th1 cells and other innate cells. Further research is needed to clarify the signaling pathways in T cells upstream of E4BP4 and the role DC-derived costimulatory molecules in this process.

\section{IL-10 AND THE DEVELOPMENT OF Tr1 CELLS}

Whereas the role of DC maturation and costimulation for the generation of $\operatorname{Tr} 1$ cells has remained poorly investigated, the requirement of IL-10 is well documented (Groux et al., 1997; Levings et al., 2005; Roncarolo et al., 2006). Indeed, differentiation of Tr1 by means of immunosuppressive drugs such as dexamethasone and vitamin D3 is inhibited even in APC-free conditions in the presence of anti-IL-10R antibodies (Barrat et al., 2002). Other studies on $\operatorname{Tr} 1$ differentiation by human immature DCs suggested that DC-derived IL-10 is critical for the generation of Tr1 cells (Levings et al., 2005; Gregori et al., 2010; van der Aar et al., 2011). The use of IL-10 reporter mice indicated that mouse Tr1 cells can develop in vivo in the absence of IL-10 (Maynard et al., 2007). It has been discussed whether IL-10 may only be required to maintain $\mathrm{T}$ cell anergy of $\operatorname{Tr} 1$ cells (Roncarolo et al., 2006). In this scenario IL-10 modulates the DC or APC maturation phenotype rather than through direct activity on T cells (Wakkach et al., 2001). Indeed, IL-10 is a potent down-modulator of MHC II and costimulatory molecule expression on DCs (Moore et al., 2001; Sato et al., 2002; Gabrysova et al., 2009; Gregori et al., 2010). Immature DCs cultured in the presence of additives such as IL-10, TGF- $\beta$, glucocorticoids or vitamin D3 analogs or low doses of GMCSF can acquire even a maturation-resistant DC phenotype, thus remaining strictly immature and generating anergic $\mathrm{T}$ cells in vitro (Lutz, 2006). However, not all such anergic T cells gain regulatory capacity (Berger et al., 2009). It remains open whether this can be explained by the fact that $\mathrm{T}$ cell anergy can result either in complete absence of CD80/CD86 signals or by CD80/CD86 engagement of CTLA-4 (Greenwald et al., 2001; Macian et al., 2004).

\section{COSTIMULATION THROUGH CD80, CD86, CD58, AND ICOS-L}

The initial report used murine splenic APCs or human monocytes to differentiate $\operatorname{Tr} 1$ cells (Groux et al., 1997). Low levels of CD80/CD86 molecules are provided by both cellular sources. However, the requirement for CD28 or CTLA-4 signals for Tr1 cell generation have initially not been addressed. Several reports demonstrated that $\operatorname{Tr} 1$ cells typically express large amounts of CTLA-4 regardless of the effector T cell type the cells were originally derived from (Table 1). Indeed, Perez et al. (2008) demonstrated that preferential ligation of CTLA- 4 by CD80 on mature DCs resulted in anergic T cells bearing suppressive activity and producing high amounts of IL-10 upon restimulation. Although the presence of anti-IL-10R antibodies abolished the differentiation of iTregs in this culture set-up, IL-10 production itself appeared largely dependent on CTLA-4 signaling (Perez et al., 2008). A role of CD58-CD2 interaction for human Tr1 has been proposed on the basis of studies using CD58-transfected artificial APCs (Levings et al., 2001; Wakkach et al., 2001). Since CD58 is not a ligand for CD2 in the mouse, this pathway may not follow a general rule for $\operatorname{Tr} 1$ generation.

Others claimed that only immature DCs contributed to the differentiation of IL-10 producing Tr1 cells (Jonuleit et al., 2000; Levings et al., 2005). However, those human immature monocytederived DCs (although largely CD83 negative) express substantial CD80 and CD86 on their cell surface (Jonuleit et al., 2000; Gregori et al., 2010) and appear thereby rather semi-mature (Lutz and Schuler, 2002), whereas these markers can be hardly detected on freshly isolated Langerhans cells (McIlroy et al., 2001), splenic DCs (Berthier-Vergnes et al., 2001), or liver perfusate DCs (Bosma et al., 2006) from human donors. Only human DCs isolated from thymus or tonsils showed substantial expression of costimulatory markers (Summers et al., 2001; Vandenabeele et al., 2001). In addition, human $\operatorname{Tr} 1$ cells could be differentiated in the presence of exogenous IL-10 and monocyte-derived DCs, which did not produce IL-12p70 but expressed high levels of costimulatory molecules on their surface (Gregori et al., 2010). Thus, costimulation through CD80/CD86 as provided by semi-mature DCs, but not by truly immature DCs, is required to generate IL- $10^{+} \mathrm{T}$ cells from naive precursors (Figure 1).

Secretion of IL-10 for both Foxp3 ${ }^{+}$Treg or Tr1 cells has been linked to high ICOS surface expression (Hutloff et al., 1999; Akbari et al., 2002; Herman et al., 2004). Costimulation via ICOS-L (CD275) on the surface of mature myeloid DCs (Witsch et al., 2002) or mature plasmacytoid DCs (Ito et al., 2007) stimulates 


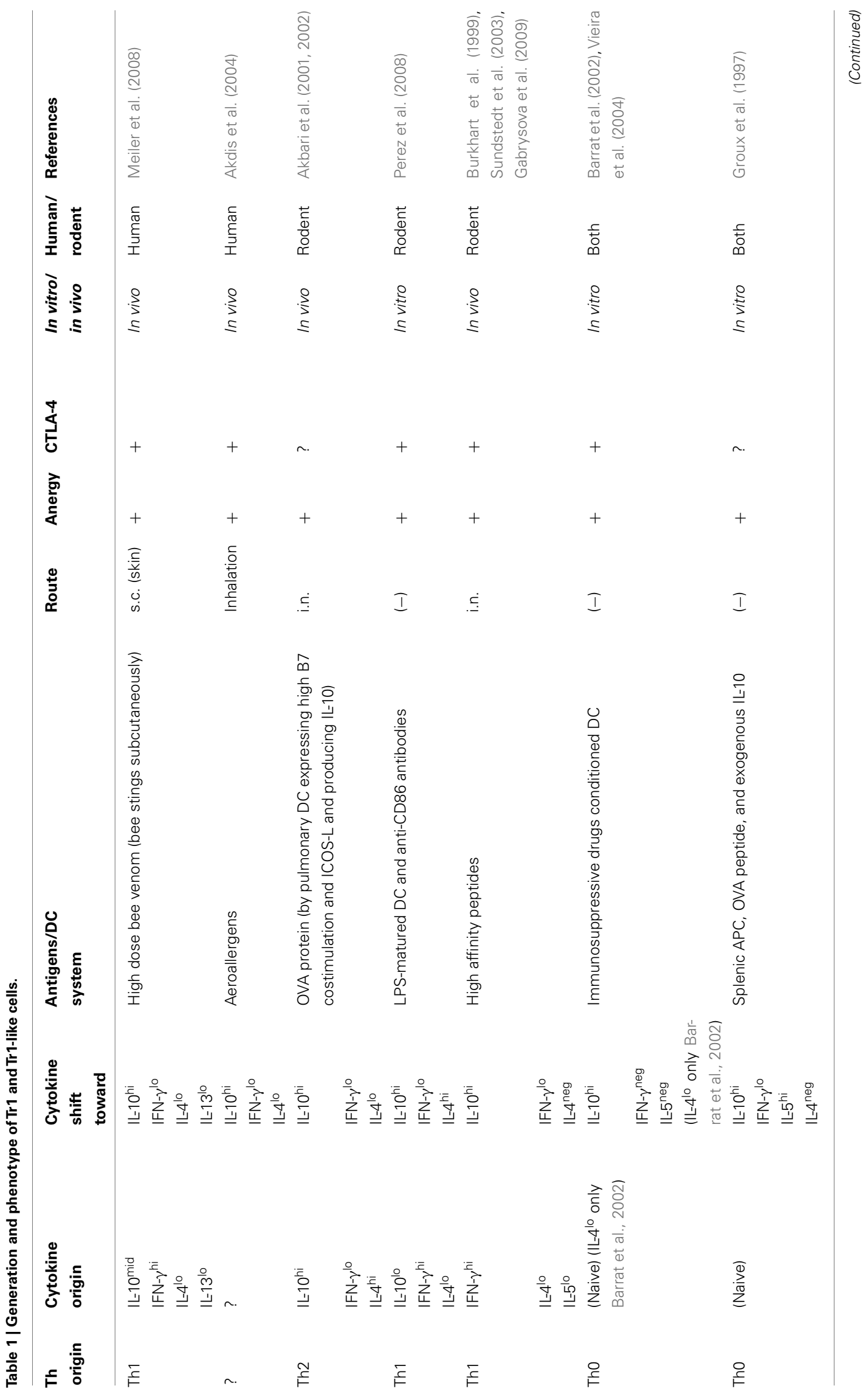




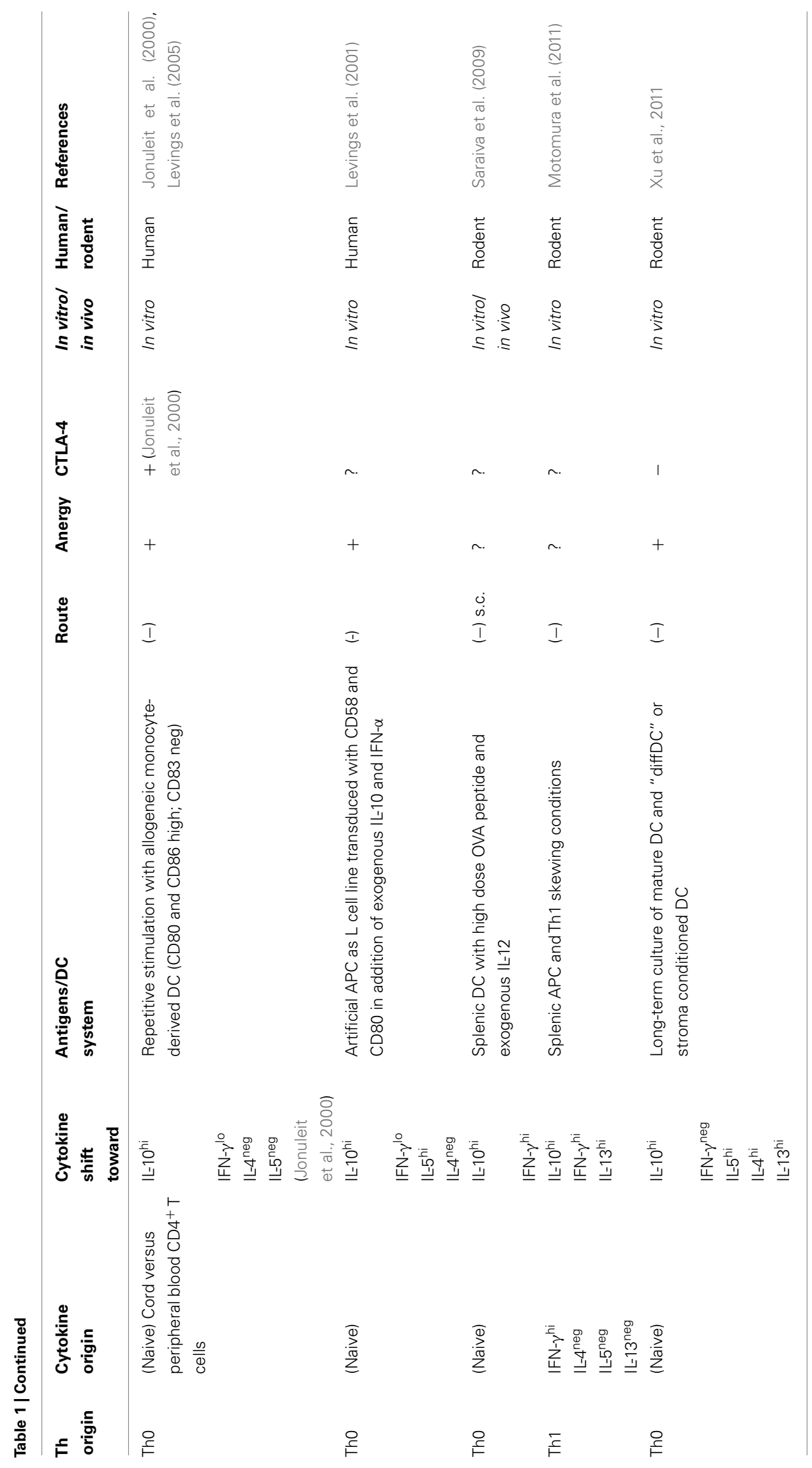


IL-10 release by $\operatorname{Tr} 1$ or $\operatorname{Tr} 1$-like cells, respectively. Enhanced expression of ICOS on in vitro generated $\mathrm{Tr} 1$ cells has also been attributed to the cytokine IL-27 (Pot et al., 2009). IL-27 can be produced by DCs upon interaction with Foxp $3^{+}$Tregs, which acquire a particular plasmacytoid-like DC phenotype expressing costimulatory molecules able to generate $\operatorname{Tr} 1$ cells (Awasthi et al., 2007). Human immature DCs specifically upregulate PD-L1 in the presence of exogenous IL-27 (Karakhanova et al., 2011). Further research is needed to define the role of a DC maturation phenotype in differentiation of $\operatorname{Tr} 1$ cells driven by exogenous IL-27 as most studies are performed under APC-free culture conditions.

Thus, some extent of costimulation by DCs seems necessary for the generation of $\operatorname{Tr} 1$ cells despite the fact that a variety of approaches have used "immature" DCs to generate Tr1 cells in vitro (Table 1).

\section{COSTIMULATION FOR Tr1-LIKE CELLS BY CHRONIC STIMULATION OF EFFECTOR T CELLS OR DURING INFECTION PLASTICITY OF T CELLS FOR PRODUCTION OF CYTOKINES OTHER THAN IL-10}

The concept of classical lineage commitment into Th1, Th2, and others has been challenged by recent work and it is suggested now that $\mathrm{T}$ cells show substantial functional plasticity in their cytokine secretion (O'Shea and Paul, 2010). As an example, IL-13 and IL10 production by Th1 cells could be demonstrated upon chronic stimulation through TCR and CD28 pathways (Motomura et al., 2011). The $\operatorname{Tr} 1$ cells described by Roncarolo and colleagues require IL-10 for their generation and then produce IL-10, some IFN- $\gamma$ and IL-5 but no IL-4 (Groux et al., 1997; Levings et al., 2001). Originally IL-10 (but also IL-5 and IL-13) was defined as a classical Th2 cytokine, however, the mechanisms and/or costimulatory signals initiating IL-10 production in Th2 cells remained unclear (Moore et al., 2001). Expression of IL-10 by Th2 memory cells has been attributed to repetitive TCR receptor signaling and continuous IL4 signals (Lohning et al., 2003; Chang et al., 2007). Alternatively, it is well established that the differentiation of IL-10 and IL-4 producing Th2 cells is CD28-signaling dependent but inhibited by CTLA-4 (Bour-Jordan et al., 2003; Coquerelle et al., 2009; Hunig et al., 2010). Indeed, injection of anti-CTLA-4 antibodies in the presence of splenic DCs induced ICOS ${ }^{+}$Tregs producing both IL-4 and IL-10 (Coquerelle et al., 2009). In contrast, triggering CTLA-4 signaling on Th1 cells by CD80 from mature DCs seems to promote IL-10 secretion and $\operatorname{Tr} 1$ differentiation (Perez et al., 2008). These observations not only emphasize the necessity of DC costimulation for the induction of IL-10 secretion in effector T cells but in addition suggest that CTLA-4 and CD28 might have opposing functions dependent on the initial differentiation program that shaped the original Th1 or Th2 cells. Furthermore, since DC-derived signals are essential in directing differential T helper cell phenotypes, it is tempting to speculate that the common signature regulating IL-10 expression in T cells is in fact driven by DC-derived costimulatory signals.

\section{Tr1-LIKE CELLS GENERATED BY TNF OR $\beta$-CATENIN STIMULATED SEMI-MATURE DCs}

Many groups, including ours, searched intensively for the DC maturation phenotype that differentiates IL- $10^{+} \operatorname{Tr} 1$-like cells from either Th1 or Th2 cells and whether this would result in tolerance or immunity (Lutz and Schuler, 2002; Lutz, 2006; Tarbell et al., 2006). Tr1-like cell generation might be initiated by triggering the $\beta$-catenin pathway in DCs, at least when induced by disrupting Ecadherin mediated homotypic interactions between DCs or after inflammatory stimulation of the DCs (Menges et al., 2002; Spörri and Reis e Sousa, 2005; Jiang et al., 2007). These DCs show a particular semi-mature phenotype characterized by high expression of MHC II and B7 costimulatory molecules but absence of cytokine secretion (Menges et al., 2002; Spörri and Reis e Sousa, 2005). Repetitive injections of such semi-mature DCs prevented the induction of experimental autoimmune encephalomyelitis (EAE) by inducing IL-10 ${ }^{+} \operatorname{Tr} 1$-like cells (Menges et al., 2002; Jiang et al., 2007 ) but also IL- $4^{+}$and IL-13 ${ }^{+}$T and NKT cells (Wiethe et al., 2007). Such TNF-stimulated semi-mature DCs were also protective in models of thyroiditis (Verginis et al., 2005) but failed to prevent CD8-mediated type-1 diabetes (Kleindienst et al., 2005). Surprisingly, semi-mature DCs deficient for the coinhibitory ligand PD-L1 (CD274) showed an increased induction of IL-10 and IL-13 secreting CD4 ${ }^{+} \mathrm{T}$ cells in vivo, indicating that $\mathrm{PD}-1$ signals counteract $\operatorname{Tr} 1$-like cell induction (Brandl et al., 2010).

It remains open at this point whether DC maturation/costimulation profiles inducing either Th2 effector cell differentiation or tolerogenic $\operatorname{Tr} 1$-like cells are different or identical.

\section{Tr1-LIKE CELLS DERIVED FROM Th2 CELLS}

Although repetitive injections of antigen-loaded semi-mature DC were able to prevent Th1-mediated diseases by inducing increasing numbers of Th2-derived Tr1-like cells with each injection (Menges et al., 2002), the same regimen failed to suppress Th2-mediated footpad swelling in a Leishmania major infection model (Wiethe et al., 2008). However, Th1-derived Tr1-like cells effectively suppressed immunity in a Th1-polarized, chronic, non-healing Leishmania major infection model (Anderson et al., 2007). Whether the differences in protection depend on the model or on differences between Th1- or Th2-derived Tr1-like cells remains unresolved. In murine parasitic infection models such as Trypanosoma brucei, Schistosoma mansoni, and Echinococcus multilocularis a cytokine shift to anti-inflammatory IL-10, IL-4, and IL-13 has been reported which is believed to protect the host from extensive tissue damage (Perona-Wright et al., 2006; Stijlemans et al., 2007; MacDonald and Maizels, 2008; Vuitton and Gottstein, 2010). The Th2/Tr1like profile induced by helminth-derived secretory products of $S$. mansoni eggs or Nippostrongylus brasiliensis excretory/secretory antigens have been shown to result in partial DC maturation (Balic et al., 2004; Perona-Wright et al., 2006). Together, parasites or their products result in immature or semi-mature DC signatures, which trigger mild TCR and costimulatory signaling cascades and result in Th2/Tr1-like polarizations. However, how DC maturation signatures regulate the master switch leading to IL-10 production in Th2 or Tr1-like cells remains to be shown.

\section{Tr1-LIKE CELLS DERIVED FROM Th1 CELLS}

The ability of Th1 differentiated T cells to produce IL-10 upon chronic stimulation is very well documented (Table 1). DCs direct Th1 differentiation as fully mature DCs by providing high TCR and costimulatory signaling in the presence of IL-12p70 cytokine 
secretion (Kapsenberg, 2003) or via CD70 signals (Soares et al., 2007). As a difference between Th1- or Th2-derived Tr1-like cells, chronic Th1 stimulation seems to be required for Tr1-like cell generation, while IL-10 release by Th2 effector T cells may occur immediately (Lohning et al., 2003; Motomura et al., 2011). Several reports indicated that the presence of IL-12 released by DCs is essential for IL-10 production in Th1 cells mediated by sustained STAT-4 signaling (Chang et al., 2007; Rutz et al., 2008; Saraiva et al., 2009). Also a high antigen dose favors their IL-10 production (Saraiva et al., 2009). IL-10 induction in Th1 cells was abrogated when DC were deficient in IL-12p40 production suggesting that IFN $-\gamma$ produced by Th1 cells induced continuous IL-12 production in DCs by a feedback loop (Saraiva et al., 2009). Alternatively, complement factors, which could be produced locally as a result of cognate DC-T cell interactions, regulated the expression of MHC II, costimulatory molecules and IL-12p70 production (Heeger and Kemper, 2011). Repetitive engagement of the complement regulator proteins CD46 or CD55 on human T cells induced IL-10 production from Th1 cells although addition of exogenous IL-2 was required (Capasso et al., 2006; Cardone et al., 2010), similar as for the generation of human Tr1 cells in vitro (Groux et al., 1997; Jonuleit et al., 2000; Levings et al., 2005). It remains open how the CD55 receptor CD97 is regulated on the DC surface. Of note, Th1 cells, which acquire the ability to produce IL-10, gradually lose their expression of IL-2 (Gabrysova et al., 2009; Saraiva et al., 2009). Sustained IL-12 driven STAT-4 signaling is also required for the IL-10 production in IFN- $\gamma$-secreting Th1 cells induced by Notch signaling (Rutz et al., 2008). Hence, it is tempting to speculate that chronic stimulations by DCs shift the intrinsic T cell polarization profile from IFN- $\gamma$ to IL-10 production. Radbruch and colleagues showed that Th1 cells up-regulate the transcription factor Twist1, which requires IL12 induced STAT-4 signaling for suppression of the Th1-effector cytokines IFN- $\gamma$, IL-2, and TNF (Niesner et al., 2008). It is worth to speculate whether this shift might be supported through CTLA-4 signals since gradual CTLA-4 upregulation by Tr1-like cells differentiated from Th1 cells has been observed regularly (Table 1). In a rejection model for organ transplantation, Th1 cells adapt to persistent antigen stimulation by upregulation of inhibitory surface molecules and cytokines such as CTLA-4, Twist1, and IL-10 (Noval Rivas et al., 2009). Earlier studies demonstrated that T cells exposed to chronic antigen stimulation down-modulate effector cytokine secretion during the process of so-called adaptive tolerance (Singh and Schwartz, 2003).

Together, IL-12 production by DCs seems to be critical for the induction of IL- 10 in Th 1 cells by triggering sustained STAT- 4 signaling. Whether the low expression of CD80/CD86 on immature DCs is sufficient or rather semi-mature or mature DCs stages are required remains open.

\section{COSTIMULATION FOR DIFFERENT Foxp3- IL-10+ iTreg TYPES IN VIVO \\ LUNG}

The generation of Tr1-like cells has been reported also in the absence of overt infections (Table 1). However, Tr1-like cell induction may require some commensal stimulation during steady state conditions through TLRs for both Th1 and Th2 responses. The mucosal application route may favor a Th2 outcome as supported by experiments where exogenous antigens were administered intranasally. The antigens could enter the respiratory but also gastrointestinal tracts and migratory DC transported the intranasally applied antigens to the draining lymph nodes to induce Th2 responses (Constant et al., 2000; Piggott et al., 2005; Derbyshire et al., 2011). Studies by Umetsu and colleagues showed that high dose antigen exposure through intranasal routes caused pulmonary DCs to mature and migrate into the draining lymph nodes where they induced IL-10 and IL-4 secreting Tr1-like cells protecting mice from airway hyper-reactivity (Akbari et al., 2001, 2002). Moreover, Akdis et al. (2004) demonstrated that a finetuned balance between aeroallergen-specific Tr1-like and Th2 cells exists in allergic or healthy patients, which may regulate allergy to common environmental proteins. How DCs or lung epithelium contribute to the generation of Th2 effector cells in lung-draining lymph nodes has been studied intensively (Hammad and Lambrecht, 2008). A mature DC signature has been revealed only by one study (Akbari et al., 2001), possibly resulting from minute amounts of endotoxin to allow DC maturation and indicating that costimulation would be required to induce Tr1-like cells.

\section{INTESTINE}

In contrast, the oral tolerance phenomenon seem to be dependent largely on DCs present in the lamina propria and mesenteric lymph nodes as shown upon administration of sugar-modified antigens, which trigger differentiation of IL-10 and IFN- $\gamma$ producing Tr1-like cells (Worbs et al., 2006; Zhou et al., 2010). It has been suggested that the presence of gut microbiota and hence, the particular IL- $10^{+}$semi-mature DC signature present under these conditions, contributes to the IL-10 production also of the T cells (Hrncir et al., 2008; Monteleone et al., 2008). TLR-2 has been previously reported to promote IL-10 production by DCs and respective Treg cell induction (Manicassamy et al., 2009). In addition, the $\beta$-catenin signaling pathway, although independent of commensal triggering, appeared critical for the tolerogenic phenotype of lamina propria DCs by promoting IL-10 production (Manicassamy et al., 2010). Okamura et al. (2009) identified lymphocyte activation gene-3 (LAG-3)-expressing Tr1-like cells in the intestine, which developed on environmental microbiota. Induction of IL-10 production by Foxp3 ${ }^{+}$iTregs resulted in response to polysaccharide A from the human commensal Bacteroides fragilis and was largely dependent on TLR-2-signaling (Round and Mazmanian, 2010). Thus, the generation of IL- $10^{+}$Tr1-like cells but also Foxp $3^{+}$iTregs in the gut under steady state conditions is heavily influenced by the local microbiological stimulation leading to DC maturation and induction of costimulation via $\beta$-catenin, TLRs, or presumably other signals.

\section{INTRAVENOUS ANTIGEN, CONVERSION FROM ANERGIC T CELLS}

In case of intravenous peptide-induced tolerance anergic $T$ cells or Tregs develop from naive precursors upon TCR receptor signaling mostly in the absence of or with weak costimulation under these steady state conditions (Thorstenson and Khoruts, 2001; Jeon et al., 2004; Safford et al., 2005). Intravenous antigen applications induce Foxp $3^{+}$Tregs as well as Foxp3 $3^{-} \operatorname{Tr} 1$ or Tr1-like cells both of which require high affinity TCR agonists (Gabrysova and Wraith, 2010; 
Gottschalk et al., 2010). While single injections of low doses of peptides suffice to generate Foxp $3^{+}$Tregs (Gottschalk et al., 2010), their $\operatorname{Tr} 1$ or $\operatorname{Tr} 1$-like counterparts are formed after several repetitive injections of high doses of peptide (Gabrysova and Wraith, 2010). Whether antigen doses and application regimens are decisive in this process is unclear. Most likely local environmental differences such as the availability of TGF- $\beta$ and all-trans retinoic acid might further contribute to Foxp3 induction (Maynard et al., $2007,2009)$. In any case, these protocols follow antigen applications in the absence of inflammatory or microbial stimulation, indicating that B7 costimulation may not be involved. Whether the resulting IL- $10^{+}$cells in these assays are $\operatorname{Tr} 1$ or $\operatorname{Tr} 1$-like cells or another subtype is unclear. On one hand they may be considered as $\operatorname{Tr} 1$ cells because they are derived from naive $\mathrm{T}$ cells under low costimulation conditions and not from polarized immunogenic Th cells. On the other hand several rounds of stimulation with strong antigenic and costimulatory conditions are more similar to Tr1-like cells. Clear genetic markers would be needed to discriminate between $\operatorname{Tr} 1$ cells, Tr1-like cells, and these IL-10 ${ }^{+} \mathrm{T}$ cells described here to clarify this point.

\section{ROLE OF COSTIMULATION FOR THE EXTRATHYMIC DE NOVO CONVERSION OF Foxp3+ iTregs}

Other major subtypes of Tregs are characterized by their expression of Foxp3. While natural Foxp $3^{+}$nTregs are directly released from the thymus independent of DCs (Kyewski and Klein, 2006; Ohkura and Sakaguchi, 2010), conversion of Foxp3 $3^{+}$iTregs occurs in peripheral lymphatic organs by interactions with DCs. The basal requirements for the development of Foxp $3^{+}$iTregs in vitro and in vivo are defined by TCR signaling and the presence of the cytokines IL-2 and TGF- $\beta$ (Figure 1; Fantini et al., 2004; Davidson et al., 2007; Curotto de Lafaille and Lafaille, 2009). In addition, costimulatory and coinhibitory molecules on the surface of DCs importantly regulate the differentiation and functions of iTregs from naive T cells (Bour-Jordan et al., 2011). Although more and more costimulatory and coinhibitory molecules of the B7 and TNF-families have been identified on DCs, which also affect peripheral $\mathrm{T}$ cell tolerance, the definite requirements for CD80/CD86 costimulation for Foxp $3^{+}$Treg biology are still under debate and therefore will be discussed here. Also PD-L1/PD-L2 heavily contribute to Treg induction and function, which is discussed in more detail elsewhere (Francisco et al., 2010) but will be briefly touched below.

\section{CD80/CD86 MOLECULES FOR Foxp3 ${ }^{+}$iTreg CONVERSION}

Initial evidence that these costimulatory molecules might play a role in Treg development reveal from studies using mice deficient for CD80/CD86 or CD28 or treated with the respective blocking antibodies. In both cases, mice exhibited markedly reduced numbers of Foxp3 ${ }^{+}$Tregs in the thymus and the periphery (Salomon et al., 2000; Bour-Jordan et al., 2004, 2011; Tang et al., 2004). However, these studies did not discriminate between effects of CD80/CD86 molecules on nTreg or iTreg development. First indications for peripherally induced iTregs come from investigations on the conversion of naïve $\mathrm{CD} 4^{+} \mathrm{CD} 25^{-} \mathrm{T}$ cells into $\mathrm{CD} 4^{+}$ CD25 ${ }^{+}$Tregs after adoptive transfer into CD80/CD86 ${ }^{-1-}$ mice (Liang et al., 2005). Under these conditions, naive CD4 ${ }^{+} \mathrm{CD} 25^{-}$
$\mathrm{T}$ cells are unable to convert into Tregs, suggesting a role of CD80/CD86 molecules in iTreg induction (Liang et al., 2005). Although in this study Tregs were not defined by expression of Foxp3, these findings are in line with our in vivo conversion data using a transgenic skin-antigen model and adoptive transfer of antigen-specific naive CD25 ${ }^{+}$Foxp $3^{-} \mathrm{T}$ cells (Azukizawa et al., 2011). In this model, elevated levels of costimulatory molecules were found on DCs migrating and transporting self-antigen under these steady state conditions, thus representing a semi-mature phenotype. These steady state migratory DCs induced peripheral conversion of naive T cells into Foxp $3^{+}$iTregs, dependent on TGF$\beta /$ latency-associated peptide (LAP) on the DC surface (Azukizawa et al., 2011). This has been also described for specific tolerogenic DC subsets in the intestine (Coombes et al., 2007; Sun et al., 2007) and spleen (Yamazaki et al., 2008). Furthermore, mature bone marrow-derived DCs could promote iTreg differentiation in vitro, but only in the presence of exogenous TGF- $\beta$ (Yamazaki et al., 2007). These reports suggest that DCs of all maturation stages are able to induce Foxp3 expressing iTregs, but the T cells prefer no or low CD28 signals. A strict requirement seems TGF- $\beta$, which can be either produced by DCs or is recruited from the environmental milieu.

\section{CD28 VERSUS CTLA-4 FOR iTreg CONVERSION}

Several studies indicate that the maturation of DCs and therefore a high costimulation is counteracting iTreg generation (Kretschmer et al., 2005; Yamazaki et al., 2007; Wang et al., 2008). Kretschmer et al. (2005) found that DC maturation in vivo upon injection of agonist anti-CD40 antibodies diminished their potential to promote iTreg conversion. In vitro Treg conversion assays with splenic DCs from $\mathrm{CD} 80^{-/-} / \mathrm{CD}^{-1-}$ mice indicated that both molecules on DCs are not directly required for the differentiation of Foxp3 ${ }^{+}$iTregs (Yamazaki et al., 2007; Wang et al., 2008) but they might promote the production of IL-2 by effector T cells, which in turn enhances iTreg generation and maintenance (Yamazaki et al., 2007). On the other hand, two studies using agonistic antiCD28 antibodies and $\mathrm{CD} 80^{-/-} / \mathrm{CD} 86^{-1-}$ mice demonstrated that at least a low CD28 costimulation was required for naive $\mathrm{T}$ cells to become iTregs, whereas strong CD28 interaction induces the differentiation of Teff cells (Benson et al., 2007; Semple et al., 2011). In this context it has to be taken into account that both effector T cells and Tregs themselves upregulate CD80 and CD86 on their surface after activation and CTLA $-4^{+}$Tregs even suppress effector $\mathrm{T}$ cells by ligating their CD80/CD86 molecules (Paust et al., 2004). In this scenario also T-T cell communication through CD28/CTLA-4 and CD80/CD86 can occur in the absence of APCs and may contribute to Treg conversion. Together, CD28 costimulation appears to counter-regulate TGF- $\beta$ dependent iTreg conversion and survival in vitro but also in vivo (Figure 1).

Unlike CD28 costimulation the interaction between CD80/CD86 molecules on DCs and CTLA-4 on T cells initially does not seem to play a role in the development of Tregs, since CTLA- $4^{-/-}$mice exhibit normal numbers of Foxp $3^{+} \mathrm{T}$ cells (Tang et al., 2004; Kataoka et al., 2005; Wing et al., 2008). Two groups further analyzed the role of CTLA-4 in the differentiation of iTregs using CTLA-4 blocking antibodies and naive CTLA-4 $4^{-/-}$T cells in Treg conversion assays in vitro (Zeng et al., 2006; Wang et al., 2008). 
Both groups found a reduced induction of Foxp3 expressing iTregs despite the presence of costimulation provided by anti-CD28 antibodies or splenic DCs (Zeng et al., 2006; Wang et al., 2008). These results cannot be explained simply by a different expression of the CTLA-4 ligands CD80/CD86 by DCs, since high costimulatory levels by anti-CD28 antibodies and low costimulatory levels by immature splenic DCs were used (Zeng et al., 2006; Wang et al., 2008). Therefore, further investigations are needed to clarify the role of CTLA-4 in iTreg development.

In this context the question remains, whether semi-mature steady state migratory DCs are tolerogenic because of or despite their costimulatory capacity. In agreement with previous results, Benson et al. (2007) could show in ex vivo studies that CD80/CD86 molecules expressed by splenic DC inhibit iTreg conversion, but administration of IL- 2 and TGF- $\beta$ in the absence or presence of retinoic acid can overcome the inhibition of iTreg differentiation, indicting a dominant role for IL- 2 and TGF- $\beta$ despite CD80/CD86 cosignaling. IL-2 production by DCs can hardly be detected under steady state conditions (Granucci et al., 2003). However, steady state migratory DCs employ endogenous TGF- $\beta$ or the TGF- $\beta$ binding partner LAP to induce Treg conversion (Azukizawa et al., 2011) and since these DCs are skin-derived and in close contact with TGF- $\beta$ producing keratinocytes, the environmental milieu in which such migratory DCs were embedded might also affect their tolerogenic potential.

Together, these observations suggest that immature costimulatory ${ }^{\text {low }}$ DCs have the highest capacity to induce iTregs in vivo and in vitro, but costimulatory ${ }^{\text {int }}$ semi-mature and costimulatory high mature DC are still able to induce iTregs. The semi-mature DC phenotype might reflect an evolutionary compromise between partial activation to upregulate CCR7 and MHC II to enable their migration to the lymph nodes and improve presentation of peripheral self-antigens with only moderate CD80/CD86 upregulation. In fact studies on human migratory DC indicated that they might maintain an immature phenotype with respect to HLA-DR and CD80/CD86 expression while CCR7 was upregulated (Geissmann et al., 2002; Verbovetski et al., 2002).

\section{PD-L1 AND PD-L2}

PD-L1 is constitutively expressed by most hematopoietic cells and can be further upregulated upon activation. In contrast, PD-L2 is inducible on DCs, macrophages, and B cells. PD-L1 and PD-L2 both are the ligands of $\mathrm{PD}-1$, which is expressed on activated $\mathrm{B}$ and T cells as well as resting Tregs (Francisco et al., 2010). The role of PD-L1 and PD-L2 for iTreg generation has been first studied by Noelle and colleagues, which showed that blocking of PD-L1, but not of PD-L2, negatively affects the induction of Foxp3 ${ }^{+}$iTregs by immature splenic DCs in vitro (Wang et al., 2008). The same group also established a tumor antigen model demonstrating that DC-derived PD-L1 was required for tumor-induced iTreg conversion (Wang et al., 2008). PD-L1 ${ }^{-/-}$mice used in this study show significant changes in their expression of other costimulatory molecules such as CD80, CD86, and CD40 (Wang et al., 2008). PD-L1 and TGF- $\beta$ play a synergistic role in the differentiation of iTregs, since both factors alone induce less iTregs in vitro than in combination (Francisco et al., 2009). In addition, mice deficient for PD-L1, PD-L2, and Rag1 have a decreased capacity to induce
iTregs in comparison with WT Rag $1^{-1-}$ mice (Francisco et al., 2009).

In sum, these data suggest a pivotal role for DC-derived PD-L1 on iTreg development. All studies described above were performed under steady state conditions or with isolated immature DC indicating that the constitutive level of PD-L1 expressed by DC is sufficient for iTreg generation.

\section{OTHER COSTIMULATORY AND COINHIBITORY MOLECULES FOR ITregS}

Despite the importance of CD80/CD86 and PD-L1/PD-L2, other regulatory molecules significantly influence iTreg conversion. Since further detailed review will be beyond the scope of this article only two examples will be mentioned. Consistent with findings from blocking CD80 and CD86 in vitro, CD40 blockage on splenic DCs increased iTreg generation (Wang et al., 2008), supporting the inhibitory effect of costimulation on Treg differentiation. In vitro conversion assays with splenic DCs treated with an agonistic GITR antibody showed a diminished induction of Foxp $3^{+} \mathrm{T}$ cells, indicating also a costimulatory role of GITR in Treg conversion (Wang et al., 2008).

\section{ROLE OF DC COSTIMULATION FOR Foxp3 ${ }^{+}$nTreg MAINTENANCE}

The TCR-specificities of natural Treg and effector $\mathrm{T}$ cell repertoires are overlapping between 10 and 40\%, depending on the study (Hsieh et al., 2004; Pacholczyk et al., 2006; Wong et al., 2007). Among the Tregs some recognize self-antigens and may continuously undergo activation in those lymph nodes where steady state migratory DCs transport and present peripheral tissue antigens to specific T cells (Fisson et al., 2003), whereas others are specific for foreign antigens derived from pathogens (Belkaid and Rouse, 2005; Kretschmer et al., 2005).

\section{CD80/CD86}

Dendritic cells can influence the expansion and survival of Tregs by different mechanism. The interaction of CD80/CD86 molecules with CD28 on Tregs is a major requirement for the thymic development and the peripheral homeostasis of Tregs (Salomon et al., 2000; Tang et al., 2003). Previous data by Bar-On et al. (2011) support this idea since CD80/CD86 provided by DC was crucial for maintenance of the peripheral Treg pool. In this study bone marrow chimeras lacking CD80/CD86 specifically on DCs were used, which result in a significantly reduced frequency and number of Tregs in the periphery, but not in the thymus (Bar-On et al., 2011). Thus, the costimulatory molecules CD80 and CD86 on DC are required to mediate Treg homeostasis. In agreement with the above described observations costimulatory high mature antigenbearing DCs induce effectively Treg expansion in vitro and in vivo (Yamazaki et al., 2003; Fehervari and Sakaguchi, 2004b). The proliferation of Tregs in those studies was dependent on CD80/CD86 expressed by DCs and small amounts of IL-2 (Yamazaki et al., 2003, 2007; Yamazaki and Steinman, 2009), which was mainly produced by effector T cells and not DCs (Fehervari and Sakaguchi, 2004b). Of note, costimulatory ${ }^{\text {low }}$ immature DCs are less effective than mature DCs in promoting Treg expansion in vitro (Fehervari and Sakaguchi, 2004a). However, under steady state conditions only immature and semi-mature DCs with basal to intermediate levels of costimulatory molecules are present in secondary 
lymphoid organs (Azukizawa et al., 2011). Fully mature DC phenotypes appear upon infection or inflammation (Lutz and Schuler, 2002) and therefore cannot play a role in Treg homeostasis. Rather mature DCs are suggested to be required for the induction of protective effector $\mathrm{T}$ cell responses and its subsequent control by Treg in two ways. First, mature DCs secrete pro-inflammatory cytokines like IL-6, which inhibit the suppressive activity of Tregs (Fehervari and Sakaguchi, 2004a). Second, by interacting of CD80/CD86 with CD28 on Tregs mature DCs may induce expansion of Tregs at the peak of the immune response resulting in the suppression of effector T cells. It remains to be determined how semi-mature DCs in comparison to immature DCs affect peripheral Treg numbers.

In this context it has to be considered that under steady state conditions lymph node resident immature DCs and migratory semi-mature DCs present self-antigens of different sources (Lutz et al., 2010; Azukizawa et al., 2011). While migratory DC take up low doses of soluble or cell-associated self-antigens in peripheral tissues, lymph node resident immature DC can only capture and present high doses of soluble antigens transported from the conduit system (Sixt et al., 2005).

\section{IL-2}

As mentioned above, DCs are also required for Treg homeostasis by inducing IL-2 production in effector T cells (Yamazaki et al., 2003, 2007; Fehervari and Sakaguchi, 2004a). IL-2, rather than IL7 and IL-15, is an essential growth factor for Tregs to survive and expand in the periphery (Figure 1; Almeida et al., 2002; Malek et al., 2002; D'Cruz and Klein, 2005; Setoguchi et al., 2005). To induce IL-2 expression in effector T cells, B7/CD28 interaction between DCs and effector T cells is required (Tang et al., 2003; Yamazaki et al., 2003, 2007). However, the contribution of DCderived IL-2 in Treg homeostasis is controversial. Whereas several in vitro studies have revealed that IL- 2 secreted by DCs plays no role in Treg maintenance (Yamazaki et al., 2003, 2007; Fehervari and Sakaguchi, 2004a), another study indicated that DC-Treg interaction via CD40/CD40L induces IL-2, which is required for Treg expansion (Guiducci et al., 2005). However, DCs have been shown to produce IL-2 only upon microbial activation but not under steady state conditions (Granucci et al., 2003). Thus, the question remains whether immature and semi-mature DCs under steady state conditions are capable to produce IL-2 and if so, what is its relevance for Tregs.

\section{Fms-LIKE TYROSINE KINASE 3 LIGAND}

The control of Treg homeostasis has also been linked to DC numbers and the level of Fms-like tyrosine kinase 3 ligand (Flt3L; Liu et al., 2003; Darrasse-Jeze et al., 2009; Swee et al., 2009; Suffner et al., 2010). Flt3L is a hematopoietic growth factor supporting proliferation and differentiation of DC precursors (Karsunky et al., 2003; Liu et al., 2003). Repetitive injections of Flt3L into mice resulted not only in an increased number of DCs, but also enhanced the proliferation of peripheral nTregs (Swee et al., 2009). In vitro experiments by the same group indicated that Flt3L-mediated nTreg expansion was directly dependent on DC contact and IL-2, but not on TCR engagement (Swee et al., 2009). In contrast, earlier studies showed that fully mature DC generated from bone marrow by GM-CSF most efficiently induced Treg expansion (Yamazaki et al., 2003), while both immature and mature Flt3L-generated bone marrow-derived DCs had a similar capacity to promote Treg proliferation (Swee et al., 2009). Others claimed that a feedback loop exists, which regulates the homeostasis of both Tregs and DCs in a Flt3L- and MHC II-dependent manner (Darrasse-Jeze et al., 2009; Hochweller et al., 2009).

\section{TONIC SIGNALS FROM MHC II MOLECULES}

Under steady state conditions T cells scan self-MHC molecules to achieve basal activation state enabling a faster subsequent response upon recognition of foreign antigens (Stefanova et al., 1989). A recent study by Hochweller et al. (2010) revealed that the responsiveness of T cells toward their cognate antigen specifically depends on the recognition of self-MHC molecules on DCs but not other APC. Since Tregs express a TCR with a higher affinity for self-MHC molecules as compared to effector T cells, it was found by twophoton microscopy in situ that antigen-presenting DCs interact for longer periods with TCR transgenic antigen-specific Tregs than effector T cells (Tadokoro et al., 2006; Tang et al., 2006). It would be interesting to investigate if such tonic TCR signals also play a role in Treg homeostasis in vivo. An initial study showed that inactivation of Lck in Tregs and thereby abrogating their TCR signaling results in an impaired proliferation and homeostatic expansion of those Tregs (Kim et al., 2009). These data indicate that DC-T cell interaction via TCR and MHC II molecules affect the maintenance of Tregs.

In sum, these observations strongly support a crucial role of DCs in Treg homeostasis and demonstrate that DCs affect the proliferation of Tregs by several mechanisms such as their expression of costimulatory molecules, surface TGF- $\beta$ /LAP, the induction of IL-2 production and their frequency in lymphoid organs.

\section{SUPPRESSIVE ACTIVITY OF Tregs ON DCs}

Despite the fact that numerous effector mechanism for Tregmediated suppression have been described (Roncarolo et al., 2006; Sakaguchi et al., 2008; Shevach, 2009; Yamazaki and Steinman, 2009; Weiner et al., 2011), the question remains, whether Tregs can act directly on effector $\mathrm{T}$ cells or all regulation occurs indirectly through DCs or other APCs? Clearly, Tregs can directly suppress $\mathrm{T}$ cell responses in vitro since APC-free co-cultures of Tregs and effector $\mathrm{T}$ cells, stimulated by CD3 and CD28 antibodies, show suppressive activities (Dieckmann et al., 2002). On the other hand major suppression mechanisms can also act on DCs, as described below. The relative contribution of both Treg targeting strategies in vivo is less well understood (Miyara and Sakaguchi, 2007; Shevach, 2009). Our own findings indicated that both direct and indirect mechanisms occur simultaneously in the spleen by using adoptively transferred DCs and CD4 ${ }^{+} \mathrm{CD} 25^{+}$ Foxp $3^{+}$Tregs. In this setting the indirect effect on DC exceeded the direct suppression of effector T cells (Hänig and Lutz, 2008).

\section{COMPETITION FOR DC}

Some published data suggest that Tregs interfere with the ability of DCs to activate effector T cells, either by physically obstructing effector $\mathrm{T}$ cells to DCs contact as shown in vitro (Onishi et al., 2008). However, competition could not be confirmed in vivo during effector $\mathrm{T}$ cell responses or under regulatory conditions 
even using high numbers of adoptively transferred mature DCs, Tregs and effector $\mathrm{T}$ cells and then following the cluster formation and sizes in spleens of mice (Hommel and Kyewski, 2003; Hänig and Lutz, 2008). Most probably, the three dimensional and highly dynamic $\mathrm{T}$ cell turnover in lymphatic organs cannot be reflected in vitro where DCs highly aggregate homotypically via E-cadherin interaction (Jakob and Udey, 1998; Riedl et al., 2000; Jiang et al., 2007).

\section{TREGS PREVENT DC MATURATION}

Tregs preclude upregulation of costimulatory molecules such as CD80, CD86, PD-L1, PD-L2, and CD40 but also the number of MHC-peptide complexes. In addition Tregs may reduce the production of inflammatory cytokines by DCs such as IL-12, IL-1 $\beta$, IL-6, and IL-8 (Fallarino et al., 2003; Misra et al., 2004; Feunou et al., 2007; Larmonier et al., 2007; Hänig and Lutz, 2008; Wing et al., 2008; Andre et al., 2009). Many of these functions remained unexplained or could be attributed to soluble factors like IL-10 or TGF- $\beta$ production by Tregs as discussed above for IL-10 by $\operatorname{Tr} 1$ and Tr1-like cells.

\section{Treg SURFACE MARKERS: LAG-3, CD39}

Onishi et al. (2008) showed that DC-Treg aggregation occurs as a first step where LAG-3, a CD4-related transmembrane protein, expressed by Tregs and activated effector T cells binds MHC II molecules on DCs, followed by CTLA-4-dependent prevention of CD86 upregulation. Additional function of LAG-3 has been described, proving that LAG-3 expressed on the Tregs surface leads to MHC II molecule crosslinking and consequential Erkmediated recruitment of SHP-1 responsible for the inhibition of DC maturation 1 (Liang et al., 2008).

Another surface molecule with immunosuppressive activity expressed by Tregs is CD39 (nucleoside triphosphate diphosphohydrolase-1), an ectoenzyme that degrades ATP to AMP. Extracellular ATP has an adjuvant feature in inflammation (Gallucci et al., 1999), whereas its degradation product AMP acts anti-inflammatory (Kumar and Sharma, 2009). CD39 expression is constitutive in Tregs and controlled by Treg master transcription factor Foxp3. After TCR ligation, the activity of membrane-bound CD39 increases (Borsellino et al., 2007).

\section{Treg SOLUBLE MEDIATORS: IL-10, TGF- $\beta$, IDO, GLUTHATHIONE}

In the early nineties it has been demonstrated that exogenous or Th cell-produced IL-10 can inhibit costimulatory function of macrophages, Langerhans cells, and DCs (Ding and Shevach, 1992; Caux et al., 1994; Péguet-Navarro et al., 1994). In most of the studies exogenous IL-10 was used, although Ding and Shevach (1992) designated a Th2 subset as a source of this cytokine. Activated $\operatorname{Tr} 1$ or Tr1-like cells are the source of IL-10 and as such prevent DC maturation (see above). Similar effects were observed with TGF- $\beta$ (Epstein et al., 1991; Bonham et al., 1996). Soon after Tregs were discovered, it was found that this cell population represents the source for both cytokines and can inhibit DC maturation in a similar manner as exogenous cytokines (Hara et al., 2001; Suri-Payer and Cantor, 2001; Belghith et al., 2003; Li et al., 2007).

Tregs express high level of CTLA-4 and several CTLA-4dependent mechanisms exist through which Tregs inhibit DC function. DCs incubated with CTLA- $4^{+}$Tregs or CTLA-4-Ig fusion proteins triggering CD80/CD86 lead to indoleamine 2,3dioxygenase (IDO) production (Fallarino et al., 2003; Feunou et al., 2007). The major effect of IDO is tryptophan degradation, causing its depletion, and the production of proapoptotic metabolites.

Another effect of the CTLA-4 interaction is Treg-mediated redox perturbation. In this case, Treg-DC contact results in CTLA4-dependent diminished glutathione (GSH) synthesis in DCs via decreased expression of $\gamma$-glutamylcysteine synthetase, the limiting enzyme for GSH synthesis (Yan et al., 2010).

Altogether, Treg-modified DCs maintaining an immature or only semi-mature status are incapable of eliciting strong, productive immune responses, and lead to induction of tolerance.

\section{DOWNREGULATION OF COSTIMULATORY MOLECULES FROM THE MATURE DC SURFACE}

While prevention of DC maturation could be a significant regulatory mechanism to avoid unwanted immunity, the question remains to which extent are mature/activated DCs sensitive to Treg cell inhibitory action? This topic has been partially assessed by several groups. Some authors claim that strong TLR-stimuli completely abrogate auto-regulation (Pasare and Medzhitov, 2003; Iwasaki and Medzhitov, 2004; Kabelitz et al., 2006). Furthermore, inflammatory cytokines produced by activated DCs seem to impede Treg functions (King and Segal, 2005; Valencia et al., 2006; Wan et al., 2007). On the other hand, although not directly addressing this question in the light of time kinetics, Veldhoen et al. (2006) could show that the repertoire of cytokine production of the LPS- and CpG-matured DCs changes from inflammatory to immunosuppressive depending on the presence of Tregs in the cultures. This result partially opposes the previous claim that strong TLR-stimuli completely disqualify Treg effects. Our own group and that of Santamaria could show that mature DCs are only partially sensitive to Tregs by modulating CD80/CD86 and PD-L1/PD-L2 but no other markers, since the Treg effect could be abrogated by CD40 licensing (Serra et al., 2003; Hänig and Lutz, 2008). Although not using additional stimuli for DC maturation beside KLH and OVA, a study of Oldenhove et al. (2003) presented convincing set of data pointing to the ability of Tregs to attenuate Th1 responses initiated by transfer of mature DCs. Remarkably, Treg depletion in the same model reflected negatively on Th2 development. Recently, a mechanism for the disappearance of CD80 and CD86 molecules on ApPCs was provided by a mechanism called trans-endocytosis, meaning the removal of individual CD80/CD86 molecules but not whole membrane patches (trogocytosis) out of the APC membrane by CTLA-4 molecules (Qureshi et al., 2011). The captured molecules are then rapidly internalized, explaining the known high turnover and predominant intracellular expression of CTLA-4.

\section{CONCLUSION}

All available data indicate that DCs interact by many means with $\mathrm{T}$ cells not only for induction of effector T cells but also to generate and maintain Tregs and in turn also to be controlled by Tregs. While TCR-specific activation is required for all Treg suppressor functions so far, the induction of $\operatorname{Tr} 1$ or $\operatorname{Tr} 1$-like cells 
clearly requires also CD80/CD86 costimulation. $\operatorname{Tr} 1$ or $\operatorname{Tr} 1$-like cell generation may be further supported by IL-10. In contrast, Foxp $3^{+}$ iTreg generation occurs more efficient without CD80/CD86 signals and requires TGF- $\beta$. The maintenance and activation of nTreg is strongly supported by high levels of CD80/CD86 and IL-2. Finally a major control mechanism of mature, but not CD40-licensed, DCs occurs through CTLA-4-dependent activity on CD80/CD86 molecules by trans-endocytosis and IDO induction at the DC-Treg interface. Future research activities, which have

\section{REFERENCES}

Akbari, O., Dekruyff, R. H., and Umetsu, D. T. (2001). Pulmonary dendritic cells producing IL-10 mediate tolerance induced by respiratory exposure to antigen. Nat. Immunol. 2, 725-731.

Akbari, O., Freeman, G. J., Meyer, E. H., Greenfield, E. A., Chang, T. T., Sharpe, A. H., Berry, G., Dekruyff, R. H., and Umetsu, D. T. (2002). Antigen-specific regulatory $\mathrm{T}$ cells develop via the ICOS-ICOSligand pathway and inhibit allergeninduced airway hyperreactivity. Nat. Med. 8, 1024-1032.

Akdis, M., Verhagen, J., Taylor, A., Karamloo, F., Karagiannidis, C., Crameri, R., Thunberg, S., Deniz, G., Valenta, R., Fiebig, H., Kegel, C., Disch, R., Schmidt-Weber, C. B., Blaser, K., and Akdis, C. A. (2004). Immune responses in healthy and allergic individuals are characterized by a fine balance between allergenspecific $\mathrm{T}$ regulatory 1 and $\mathrm{T}$ helper 2 cells. J. Exp. Med. 199, 1567-1575.

Almeida, A. R., Legrand, N., Papiernik, M., and Freitas, A. A. (2002). Homeostasis of peripheral CD4+ T cells: IL-2R alpha and IL2 shape a population of regulatory cells that controls CD4+ $\mathrm{T}$ cell numbers. J. Immunol. 169, 4850-4860.

Anderson, C. F., Oukka, M., Kuchroo, V. J., and Sacks, D. (2007). CD4(+)CD25(-)Foxp3(-) Th1 cells are the source of IL-10mediated immune suppression in chronic cutaneous leishmaniasis. J. Exp. Med. 204, 285-297.

Andre, S., Tough, D. F., LacroixDesmazes, S., Kaveri, S. V., and Bayry, J. (2009). Surveillance of antigenpresenting cells by CD4+ CD25+ regulatory $\mathrm{T}$ cells in autoimmunity: immunopathogenesis and therapeutic implications. Am. J. Pathol. 174, 1575-1587.

Awasthi, A., Carrier, Y., Peron, J. P., Bettelli, E., Kamanaka, M., Flavell, R. A., Kuchroo, V. K., Oukka, M., and Weiner, H. L. (2007). A dominant function for interleukin 27 in generating interleukin 10-producing anti-inflammatory $\mathrm{T}$ cells. Nat. Immunol. 8, 1380-1389.

Azukizawa, H., Döhler, A., Kanazawa, N., Nayak, A., Lipp, M., Malissen, B., Autenrieth, I., Katayama, I., Riemann, M., Weih, F., BerberichSiebelt, F., and Lutz, M. B. (2011). Steady state migratory RelB+ Langerin+ dermal dendritic cells mediate peripheral induction of antigen-specific $\mathrm{CD} 4+\mathrm{CD} 25+$ Foxp3+ regulatory T cells. Eur. J. Immunol. 41, 1420-1434.

Balic, A., Harcus, Y., Holland, M. J., and Maizels, R. M. (2004). Selective maturation of dendritic cells by Nippostrongylus brasiliensis-secreted proteins drives Th2 immune responses. Eur. J. Immunol. 34, 3047-3059.

Bar-On, L., Birnberg, T., Kim, K. W., and Jung, S. (2011). Dendritic cell-restricted CD80/86 deficiency results in peripheral regulatory $\mathrm{T}$ cell reduction but is not associated with lymphocyte hyperactivation. Eur. J. Immunol. 41, 291-298.

Barrat, F. J., Cua, D. J., Boonstra, A., Richards, D. F., Crain, C., Savelkoul, H. F., De Waal-Malefyt, R., Coffman, R. L., Hawrylowicz, C. M., and O'garra, A. (2002). In vitro generation of interleukin 10-producing regulatory $\mathrm{CD} 4(+) \mathrm{T}$ cells is induced by immunosuppressive drugs and inhibited by $\mathrm{T}$ helper type 1 (Th1)and Th2-inducing cytokines. J. Exp. Med. 195, 603-616.

Belghith, M., Bluestone, J. A., Barriot, S., Megret, J., Bach, J. F., and Chatenoud, L. (2003). TGFbeta-dependent mechanisms mediate restoration of self-tolerance induced by antibodies to CD3 in overt autoimmune diabetes. Nat. Med. 9, 1202-1208.

Belkaid, Y., and Rouse, B. T. (2005). Natural regulatory $\mathrm{T}$ cells in infectious disease. Nat. Immunol. 6, 353-360.

Benson, M. J., Pino-Lagos, K., Rosemblatt, M., and Noelle, R. J. (2007). All-trans retinoic acid mediates enhanced $\mathrm{T}$ reg cell growth, differentiation, and gut homing

to consider also the CD80/CD86 expression on activated Tregs and effector $\mathrm{T}$ cells, will lead to a more complete understanding of these molecules and how this can be exploited to develop new therapies.

\section{ACKNOWLEDGMENTS}

The authors performed studies on tolerogenic DC, polarized Th2/Tr 1 cells and Foxp $3^{+}$Tregs that were supported by the Deutsche Forschungsgemeinschaft (DFG) by fellowships within the TR52, SFB581, and IRTG1522.

in the face of high levels of co-stimulation. J. Exp. Med. 204, 1765-1774.

Berger, T. G., Schulze-Koops, H., Schafer, M., Muller, E., and Lutz, M. B. (2009). Immature and maturation-resistant human dendritic cells generated from bone marrow require two stimulations to induce $\mathrm{T}$ cell anergy in vitro. PLoS ONE 4, e6645. doi: 10.1371/journal.pone. 0006645

Berthier-Vergnes, O., Gaucherand, M., Peguet-Navarro, J., Plouet, J., Pageaux, J. F., Schmitt, D., and Staquet, M. J. (2001). Human melanoma cells inhibit the earliest differentiation steps of human Langerhans cell precursors but failed to affect the functional maturation of epidermal Langerhans cells. Br. J. Cancer 85, 1944-1951.

Bettini, M., and Vignali, D. A. (2009). Regulatory $\mathrm{T}$ cells and inhibitory cytokines in autoimmunity. Curr. Opin. Immunol. 21, 612-618.

Bonham, C. A., Lu, L., Banas, R. A., Fontes, P., Rao, A. S., Starzl, T. E., Zeevi, A., and Thomson, A. W. (1996). TGF-beta 1 pretreatment impairs the allostimulatory function of human bone marrowderived antigen-presenting cells for both naive and primed $\mathrm{T}$ cells. Transpl. Immunol. 4, 186-191.

Borsellino, G., Kleinewietfeld, M., Di Mitri, D., Sternjak, A., Diamantini, A., Giometto, R., Hopner, S., Centonze, D., Bernardi, G., Dell'acqua, M. L., Rossini, P. M., Battistini, L., Rotzschke, O., and Falk, K. (2007). Expression of ectonucleotidase CD39 by Foxp3+ Treg cells: hydrolysis of extracellular ATP and immune suppression. Blood 110 , 1225-1232.

Bosma, B. M., Metselaar, H. J., Mancham, S., Boor, P. P., Kusters, J. G., Kazemier, G., Tilanus, H. W., Kuipers, E. J., and Kwekkeboom, J. (2006). Characterization of human liver dendritic cells in liver grafts and perfusates. Liver Transpl. 12, 384-393.

Bour-Jordan, H., Esensten, J. H. Martinez-Llordella, M., Penaranda,
C., Stumpf, M., and Bluestone, J. A. (2011). Intrinsic and extrinsic control of peripheral T-cell tolerance by costimulatory molecules of the CD28/B7 family. Immunol. Rev. 241, 180-205.

Bour-Jordan, H., Grogan, J. L., Tang, Q., Auger, J. A., Locksley, R. M., and Bluestone, J. A. (2003). CTLA4 regulates the requirement for cytokine-induced signals in $\mathrm{T}(\mathrm{H}) 2$ lineage commitment. Nat. Immunol. 4, 182-188.

Bour-Jordan, H., Salomon, B. L., Thompson, H. L., Szot, G. L., Bernhard, M. R., and Bluestone, J. A (2004). Costimulation controls diabetes by altering the balance of pathogenic and regulatory T cells. J. Clin. Invest. 114, 979-987.

Brandl, C., Ortler, S., Herrmann, T., Cardell, S., Lutz, M. B., and Wiendl, H. (2010). B7-H1-deficiency enhances the potential of tolerogenic dendritic cells by activating CD1d-restricted type II NKT cells. PLOS ONE 5, e10800. doi: 10.1371/journal.pone.0010800

Burkhart, C., Liu, G. Y., Anderton, S. M., Metzler, B., and Wraith, D. C. (1999). Peptide-induced T cell regulation of experimental autoimmune encephalomyelitis: a role for IL-10. Int. Immunol. 11, 1625-1634.

Capasso, M., Durrant, L. G., Stacey, M., Gordon, S., Ramage, J., and Spendlove, I. (2006). Costimulation via CD55 on human CD4+ T cells mediated by CD97. J. Immunol. 177, 1070-1077.

Cardone, J., Le Friec, G., Vantourout, P., Roberts, A., Fuchs, A., Jackson, I., Suddason, T., Lord, G., Atkinson, J. P., Cope, A., Hayday, A., and Kemper, C. (2010) Complement regulator CD46 temporally regulates cytokine production by conventional and unconventional T cells. Nat. Immunol. 11, 862-871.

Caux, C., Massacrier, C., Vanbervliet, B., Barthelemy, C., Liu, Y. J., and Banchereau, J. (1994). Interleukin 10 inhibits $\mathrm{T}$ cell alloreaction induced by human dendritic cells. Int. Immunol. 6, 1177-1185. 
Chang, H. D., Helbig, C., Tykocinski, L., Kreher, S., Koeck, J., Niesner, U., and Radbruch, A. (2007). Expression of IL-10 in Th memory lymphocytes is conditional on IL-12 or IL-4, unless the IL-10 gene is imprinted by GATA-3. Eur. J. Immunol. 37, 807-817.

Collins, A. V., Brodie, D. W., Gilbert, R. J., Iaboni, A., Manso-Sancho, R., Walse, B., Stuart, D. I., Van Der Merwe, P. A., and Davis, S. J. (2002). The interaction properties of costimulatory molecules revisited. Immunity 17, 201-210.

Constant, S. L., Lee, K. S., and Bottomly, K. (2000). Site of antigen delivery can influence $\mathrm{T}$ cell priming: pulmonary environment promotes preferential Th2-type differentiation. Eur. J. Immunol. 30, 840-847.

Coombes, J. L., Siddiqui, K. R., Arancibia-Carcamo, C. V., Hall, J., Sun, C. M., Belkaid, Y., and Powrie, F. (2007). A functionally specialized population of mucosal CD103+ DCs induces Foxp3+ regulatory $\mathrm{T}$ cells via a TGF-beta and retinoic acid-dependent mechanism. J. Exp. Med. 204, 1757-1764.

Coquerelle, C., Oldenhove, G., Acolty, V., Denoeud, J., Vansanten, G., Verdebout, J. M., Mellor, A., Bluestone, J. A., and Moser, M. (2009). Anti-CTLA-4 treatment induces IL10-producing ICOS+ regulatory $\mathrm{T}$ cells displaying IDO-dependent anti-inflammatory properties in a mouse model of colitis. Gut 58, 1363-1373.

Curotto de Lafaille, M. A., and Lafaille, J. J. (2009). Natural and adaptive foxp3+ regulatory $\mathrm{T}$ cells: more of the same or a division of labor? Immunity 30, 626-635.

Darrasse-Jeze, G., Deroubaix, S., Mouquet, H., Victora, G. D., Eisenreich, T., Yao, K. H., Masilamani, R. F., Dustin, M. L., Rudensky, A., Liu, K., and Nussenzweig, M. C. (2009). Feedback control of regulatory $\mathrm{T}$ cell homeostasis by dendritic cells in vivo. J. Exp. Med. 206, 1853-1862.

Davidson, T. S., Dipaolo, R. J., Andersson, J., and Shevach, E. M. (2007). Cutting Edge: IL-2 is essential for TGF-beta-mediated induction of Foxp $3+\mathrm{T}$ regulatory cells. $J$. Immunol. 178, 4022-4026.

D'Cruz, L. M., and Klein, L. (2005). Development and function of agonist-induced CD25+Foxp3+ regulatory $\mathrm{T}$ cells in the absence of interleukin 2 signaling. Nat. Immunol. 6, 1152-1159.

Derbyshire, K., Addey, C., Coe, D., Stuckey, D. W., Muezzin, H., Bubier, J. A., Shaffer, D. J., Roopenian, D.
C., Chai, J. G., and Scott, D. M. (2011). Molecular mechanisms of induction of antigen-specific allograft tolerance by intranasal peptide administration. J. Immunol. 186, 5719-5728.

Dieckmann, D., Bruett, C. H., Ploettner, H., Lutz, M. B., and Schuler, G. (2002). Human CD4(+)CD25(+) regulatory, contact-dependent $\mathrm{T}$ cells induce interleukin 10producing, contact-independent type 1-like regulatory $\mathrm{T}$ cells [corrected]. J. Exp. Med. 196, 247-253.

Ding, L., and Shevach, E. (1992). IL10 inhibits mitogen-induced $\mathrm{T}$ cell proliferation by selectively inhibiting macrophage costimulatory function. J. Immunol. 148, 3133-3139.

Epstein, S. P., Baer, R. L., Thorbecke, G. J., and Belsito, D. V. (1991). Immunosuppressive effects of transforming growth factor beta: inhibition of the induction of Ia antigen on Langerhans cells by cytokines and of the contact hypersensitivity response. J. Invest. Dermatol. 96, 832-837.

Fallarino, F., Grohmann, U., Hwang, K. W., Orabona, C., Vacca, C., Bianchi, R., Belladonna, M. L., Fioretti, M. C., Alegre, M. L., and Puccetti, P. (2003). Modulation of tryptophan catabolism by regulatory T cells. Nat. Immunol. 4, 1206-1212.

Fantini, M. C., Becker, C., Monteleone, G., Pallone, F., Galle, P. R., and Neurath, M. F. (2004). Cutting edge: TGF-beta induces a regulatory phenotype in CD4+CD25- $\mathrm{T}$ cells through Foxp3 induction and downregulation of Smad7. J. Immunol. 172, 5149-5153.

Fehervari, Z., and Sakaguchi, S. (2004a). Control of Foxp3+ CD25+CD4+ regulatory cell activation and function by dendritic cells. Int. Immunol. 16, 1769-1780.

Fehervari, Z., and Sakaguchi, S. (2004b). Development and function of CD25+CD4+ regulatory T cells. Curr. Opin. Immunol. 16, 203-208.

Feuerer, M., Hill, J. A., Kretschmer, K., Von Boehmer, H., Mathis, D., and Benoist, C. (2010). Genomic definition of multiple ex vivo regulatory $\mathrm{T}$ cell subphenotypes. Proc. Natl. Acad. Sci. U.S.A. 107, 5919-5924.

Feunou, P., Vanwetswinkel, S., Gaudray, F., Goldman, M., Matthys, P., and Braun, M. Y. (2007). Foxp3+CD25+ $\mathrm{T}$ regulatory cells stimulate IFN-gammaindependent CD152-mediated activation of tryptophan catabolism that provides dendritic cells with immune regulatory activity in mice unresponsive to staphylococcal enterotoxin B. J. Immunol. 179, 910-917.

Filaci, G., and Suciu-Foca, N. (2002). $\mathrm{CD} 8+\mathrm{T}$ suppressor cells are back to the game: are they players in autoimmunity? Autoimmun. Rev. 1 , 279-283.

Fisson, S., Darrasse-Jeze, G., Litvinova, E., Septier, F., Klatzmann, D., Liblau, R., and Salomon, B. L. (2003). Continuous activation of autoreactive $\mathrm{CD} 4+\mathrm{CD} 25+$ regulatory $\mathrm{T}$ cells in the steady state. J. Exp. Med. 198, 737-746.

Francisco, L. M., Sage, P. T., and Sharpe, A. H. (2010). The PD-1 pathway in tolerance and autoimmunity. Immunol. Rev. 236, 219-242.

Francisco, L. M., Salinas, V. H., Brown, K. E., Vanguri, V. K., Freeman, G. J., Kuchroo, V. K., and Sharpe, A. H. (2009). PD-L1 regulates the development, maintenance, and function of induced regulatory T cells. J. Exp. Med. 206, 3015-3029.

Gabrysova, L., Nicolson, K. S., Streeter, H. B., Verhagen, J., Sabatos-Peyton, C. A., Morgan, D. J., and Wraith, D. C. (2009). Negative feedback control of the autoimmune response through antigen-induced differentiation of IL-10-secreting Th1 cells. J. Exp. Med. 206, 1755-1767.

Gabrysova, L., and Wraith, D. C. (2010). Antigenic strength controls the generation of antigen-specific IL-10secreting $\mathrm{T}$ regulatory cells. Eur. J. Immunol. 40, 1386-1395.

Gallucci, S., Lolkema, M., and Matzinger, P. (1999). Natural adjuvants: endogenous activators of dendritic cells. Nat. Med. 5, 1249-1255.

Geissmann, F., Dieu-Nosjean, M. C., Dezutter, C., Valladeau, J., Kayal, S., Leborgne, M., Brousse, N., Saeland, S., and Davoust, J. (2002). Accumulation of immature Langerhans cells in human lymph nodes draining chronically inflamed skin. J. Exp. Med. 196, 417-430.

Gottschalk, R. A., Corse, E., and Allison, J. P. (2010). TCR ligand density and affinity determine peripheral induction of Foxp3 in vivo. J. Exp. Med. 207, 1701-1711.

Granucci, F., Feau, S., Angeli, V., Trottein, F., and Ricciardi-Castagnoli, P. (2003). Early IL-2 production by mouse dendritic cells is the result of microbial-induced priming. $J$. Immunol. 170, 5075-5081.

Greenwald, R. J., Boussiotis, V. A., Lorsbach, R. B., Abbas, A. K., and Sharpe, A. H. (2001). CTLA-4 regulates induction of anergy in vivo. Immunity 14, 145-155.

Gregori, S., Tomasoni, D., Pacciani, V., Scirpoli, M., Battaglia, M., Magnani,
C. F., Hauben, E., and Roncarolo, M. G. (2010). Differentiation of type $1 \mathrm{~T}$ regulatory cells $(\operatorname{Tr} 1)$ by tolerogenic DC-10 requires the IL-10-dependent ILT4/HLA-G pathway. Blood 116, 935-944.

Groux, H., O'garra, A., Bigler, M., Rouleau, M., Antonenko, S., De Vries, J. E., and Roncarolo, M. G. (1997). A CD4+ T-cell subset inhibits antigen-specific $\mathrm{T}$ cell responses and prevents colitis. Nature 389, 737-742.

Guiducci, C., Valzasina, B., Dislich, H., and Colombo, M. (2005). CD40/CD40L interaction regulates $\mathrm{CD} 4+\mathrm{CD} 25+\mathrm{T}$ reg homeostasis through dendritic cellproduced IL-2. Eur. J. Immunol. 35, 557-567.

Hammad, H., and Lambrecht, B. N. (2008). Dendritic cells and epithelial cells: linking innate and adaptive immunity in asthma. Nat. Rev Immunol. 8, 193-204.

Hänig, J., and Lutz, M. B. (2008). Suppression of mature dendritic cell function by regulatory $\mathrm{T}$ cells in vivo is abrogated by CD40 licensing. $J$. Immunol. 180, 1405-1413.

Hara, M., Kingsley, C. I., Niimi, M., Read, S., Turvey, S. E., Bushell, A. R., Morris, P. J., Powrie, F., and Wood, K. J. (2001). Il-10 is required for regulatory $\mathrm{t}$ cells to mediate tolerance to alloantigens in vivo. J. Immunol. 166, 3789-3796.

Hawrylowicz, C. M., and O'Garra, A. (2005). Potential role of interleukin10 -secreting regulatory $\mathrm{T}$ cells in allergy and asthma. Nat. Rev. Immunol. 5, 271-283.

Heeger, P. S., and Kemper, C. (2011). Novel roles of complement in $\mathrm{T}$ effector cell regulation. Immunobiology doi:10.1016/j.imbio.2011.06.004. [Epub ahead of print].

Herman, A. E., Freeman, G. J., Mathis, D., and Benoist, C. (2004) $\mathrm{CD} 4+\mathrm{CD} 25+\mathrm{T}$ regulatory cells dependent on ICOS promote regulation of effector cells in the prediabetic lesion. J. Exp. Med. 199, 1479-1489.

Hochweller, K., Miloud, T., Striegler, J., Naik, S., Hammerling, G. J., and Garbi, N. (2009). Homeostasis of dendritic cells in lymphoid organs is controlled by regulation of their precursors via a feedback loop. Blood 114, 4411-4421.

Hochweller, K., Wabnitz, G. H., Samstag, Y., Suffner, J., Hammerling, G. J., and Garbi, N. (2010). Dendritic cells control $\mathrm{T}$ cell tonic signaling required for responsiveness to foreign antigen. Proc. Natl. Acad. Sci. U.S.A. 107, 5931-5936. 
Hommel, M., and Kyewski, B. (2003). Dynamic changes during the immune response in T cell-antigenpresenting cell clusters isolated from lymph nodes. J. Exp. Med. 197, 269-280.

Horwitz, D. A., Zheng, S. G., and Gray, J. D. (2008). Natural and TGFbeta-induced Foxp3(+)CD4(+) $\mathrm{CD} 25(+)$ regulatory $\mathrm{T}$ cells are not mirror images of each other. Trends Immunol. 29, 429-435.

Hrncir, T., Stepankova, R., Kozakova, H., Hudcovic, T., and TlaskalovaHogenova, H. (2008). Gut microbiota and lipopolysaccharide content of the diet influence development of regulatory $\mathrm{T}$ cells: studies in germ-free mice. BMC Immunol. 9, 65. doi: 10.1186/1471-21729-65

Hsieh, C. S., Liang, Y., Tyznik, A. J., Self, S. G., Liggitt, D., and Rudensky, A. Y. (2004). Recognition of the peripheral self by naturally arising CD25+ CD4+ T cell receptors. Immunity 21 , 267-277.

Hunig, T., Luhder, F., Elflein, K., Gogishvili, T., Frohlich, M., Guler, R., Cutler, A., and Brombacher, F. (2010). CD28 and IL-4: two heavyweights controlling the balance between immunity and inflammation. Med. Microbiol. Immunol. 199, 239-246.

Hutloff, A., Dittrich, A. M., Beier, K. C., Eljaschewitsch, B., Kraft, R., Anagnostopoulos, I., and Kroczek, R. A. (1999). ICOS is an inducible T-cell co-stimulator structurally and functionally related to CD28. Nature 397 , 263-266.

Ito, T., Yang, M., Wang, Y. H., Lande, R., Gregorio, J., Perng, O. A., Qin, X. F., Liu, Y. J., and Gilliet, M. (2007). Plasmacytoid dendritic cells prime IL-10-producing $\mathrm{T}$ regulatory cells by inducible costimulator ligand. $J$. Exp. Med. 204, 105-115.

Iwasaki, A., and Medzhitov, R. (2004). Toll-like receptor control of the adaptive immune responses. Nat. Immunol. 5, 987-995.

Jakob, T., and Udey, M. C. (1998). Regulation of E-cadherin-mediated adhesion in Langerhans cell-like dendritic cells by inflammatory mediators that mobilize Langerhans cells in vivo. J. Immunol. 160, 4067-4073.

Jeon, M. S., Atfield, A., Venuprasad, K., Krawczyk, C., Sarao, R., Elly, C., Yang, C., Arya, S., Bachmaier, K., Su, L., Bouchard, D., Jones, R., Gronski, M., Ohashi, P., Wada, T., Bloom, D., Fathman, C. G., Liu, Y. C., and Penninger, J. M. (2004). Essential role of the $\mathrm{E} 3$ ubiquitin ligase Cbl-b in T cell anergy induction. Immunity 21, 167-177.

Jiang, A., Bloom, O., Ono, S., Cui, W., Unternaehrer, J., Jiang, S., Whitney, J. A., Connolly, J., Banchereau, J., and Mellman, I. (2007). Disruption of E-cadherin-mediated adhesion induces a functionally distinct pathway of dendritic cell maturation. Immunity 27, 610-624.

Jonuleit, H., Schmitt, E., Schuler, G., Knop, J., and Enk, A. H. (2000). Induction of interleukin 10-producing, nonproliferating $\mathrm{CD} 4(+) \mathrm{T}$ cells with regulatory properties by repetitive stimulation with allogeneic immature human dendritic cells. J. Exp. Med. 192, 1213-1222.

Kabelitz, D., Wesch, D., and Oberg, H. H. (2006). Regulation of regulatory $\mathrm{T}$ cells: role of dendritic cells and tolllike receptors. Crit. Rev. Immunol. 26, 291-306.

Kapsenberg, M. L. (2003). Dendriticcell control of pathogen-driven Tcell polarization. Nat. Rev. Immunol. 3, 984-993.

Karakhanova, S., Bedke, T., Enk, A. H., and Mahnke, K. (2011). IL-27 renders DC immunosuppressive by induction of B7-H1. J. Leukoc. Biol. 89, 837-845.

Karsunky, H., Merad, M., Cozzio, A., Weissman, I. L., and Manz, M. G. (2003). Flt3 ligand regulates dendritic cell development from Flt3+ lymphoid and myeloid-committed progenitors to Flt3+ dendritic cells in vivo. J. Exp. Med. 198, 305-313.

Kataoka, H., Takahashi, S., Takase, K., Yamasaki, S., Yokosuka, T., Koike, T., and Saito, T. (2005). $\mathrm{CD} 25(+) \mathrm{CD} 4(+)$ regulatory $\mathrm{T}$ cells exert in vitro suppressive activity independent of CTLA-4. Int. Immunol. 17, 421-427.

Kim, J. K., Klinger, M., Benjamin, J., Xiao, Y., Erle, D. J., Littman, D. R., and Killeen, N. (2009). Impact of the TCR signal on regulatory $\mathrm{T}$ cell homeostasis, function, and trafficking. PLOS ONE 4, e6580. doi: 10.1371/journal.pone.0006580

King, I. L., and Segal, B. M. (2005). Cutting edge: IL-12 induces $\mathrm{CD} 4+\mathrm{CD} 25-\mathrm{T}$ cell activation in the presence of $\mathrm{T}$ regulatory cells. $J$. Immunol. 175, 641-645.

Kleindienst, P., Wiethe, C., Lutz, M. B., and Brocker, T. (2005). Simultaneous induction of $\mathrm{CD} 4 \mathrm{~T}$ cell tolerance and CD8 $\mathrm{T}$ cell immunity by semimature dendritic cells. J. Immunol. 174, 3941-3947.

Kretschmer, K., Apostolou, I., Hawiger, D., Khazaie, K., Nussenzweig, M. C., and Von Boehmer, H. (2005).
Inducing and expanding regulatory $\mathrm{T}$ cell populations by foreign antigen. Nat. Immunol. 6, 1219-1227.

Kumar, V., and Sharma, A. (2009). Adenosine: an endogenous modulator of innate immune system with therapeutic potential. Eur. J. Pharmacol. 616, 7-15.

Kyewski, B., and Klein, L. (2006). A central role for central tolerance. Annu. Rev. Immunol. 24, 571-606.

Larmonier, N., Marron, M., Zeng, Y., Cantrell, J., Romanoski, A., Sepassi, M., Thompson, S., Chen, X., Andreansky, S., and Katsanis, E. (2007). Tumor-derived $\mathrm{CD} 4(+) \mathrm{CD} 25(+)$ regulatory $\mathrm{T}$ cell suppression of dendritic cell function involves TGF-beta and IL-10. Cancer Immunol. Immunother. 56 48-59.

Lenschow, D. J., Su, G. H., Zuckerman, L. A., Nabavi, N., Jellis, C. L., Gray, G. S., Miller, J., and Bluestone, J. A. (1993). Expression and functional significance of an additional ligand for CTLA-4. Proc. Natl. Acad. Sci. U.S.A. 90, 11054-11058.

Levings, M. K., Gregori, S., Tresoldi, E., Cazzaniga, S., Bonini, C., and Roncarolo, M. G. (2005). Differentiation of Tr1 cells by immature dendritic cells requires IL-10 but not CD25+CD4+ Tr cells. Blood 105, 1162-1169.

Levings, M. K., Sangregorio, R., Galbiati, F., Squadrone, S., De Waal Malefyt, R., and Roncarolo, M. G. (2001). IFN-alpha and IL-10 induce the differentiation of human type 1 $\mathrm{T}$ regulatory cells. J. Immunol. 166 , 5530-5539.

Li, M. O., Wan, Y. Y., and Flavell, R. A. (2007). T cell-produced transforming growth factor-betal controls $\mathrm{T}$ cell tolerance and regulates Th1- and Th17-cell differentiation. Immunity 26, 579-591.

Liang, B., Workman, C., Lee, J., Chew, C., Dale, B. M., Colonna, L., Flores, M. Li, N., Schweighoffer, E., Greenberg, S., Tybulewicz, V., Vignali, D., and Clynes, R. (2008). Regulatory T cells inhibit dendritic cells by lymphocyte activation gene- 3 engagement of MHC class II. J. Immunol. 180 , 5916-5926.

Liang, S., Alard, P., Zhao, Y., Parnell, S., Clark, S. L., and Kosiewicz, M. M. (2005). Conversion of CD4+ CD25cells into CD4+ CD25+ regulatory $\mathrm{T}$ cells in vivo requires $\mathrm{B} 7$ costimulation, but not the thymus. J. Exp. Med. 201, 127-137.

Liu, Y., Huang, H., Chen, Z., Zong, L., and Xiang, J. (2003). Dendritic cells engineered to express the Flt3 ligand stimulate type I immune response, and induce enhanced cytoxic $\mathrm{T}$ and natural killer cell cytotoxicities and antitumor immunity. J. Gene Med. 5, 668-680.

Lohning, M., Richter, A., Stamm, T., HuLi, J., Assenmacher, M., Paul, W. E., and Radbruch, A. (2003). Establishment of memory for IL-10 expression in developing $\mathrm{T}$ helper 2 cells requires repetitive IL-4 costimulation and does not impair proliferation. Proc. Natl. Acad. Sci. U.S.A. 100, 12307-12312.

Lutz, M. B. (2006). "Differentiation stages and subsets of tolerogenic dendritic cells," in Handbook of Dendritic Cells: Biology, Diseases and Therapy, eds. M. B. Lutz, N. Romani, and A. Steinkasserer (Weinheim: VCH-Wiley), 517-543.

Lutz, M. B., Dohler, A., and Azukizawa, H. (2010). Revisiting the tolerogenicity of epidermal Langerhans cells. Immunol. Cell Biol. 88 381-386.

Lutz, M. B., and Schuler, G. (2002). Immature, semi-mature and fully mature dendritic cells: which signals induce tolerance or immunity? Trends Immunol. 23, 445-449.

MacDonald, A. S., and Maizels, R. M. (2008). Alarming dendritic cells for Th2 induction. J. Exp. Med. 205, 13-17.

Macian, F., Im, S. H., Garcia-Cozar, F. J., and Rao, A. (2004). T-cell anergy. Curr. Opin. Immunol. 16, 209-216.

Malek, T. R., Yu, A., Vincek, V., Scibelli, P., and Kong, L. (2002). CD4 regulatory $\mathrm{T}$ cells prevent lethal autoimmunity in IL-2Rbeta-deficient mice. Implications for the nonredundant function of IL-2. Immunity 17, 167-178.

Manicassamy, S., Ravindran, R., Deng, J., Oluoch, H., Denning, T. L., Kasturi, S. P., Rosenthal, K. M., Evavold, B. D., and Pulendran, B. (2009). Tolllike receptor 2-dependent induction of vitamin A-metabolizing enzymes in dendritic cells promotes $T$ regulatory responses and inhibits autoimmunity. Nat. Med. 15, 401-409.

Manicassamy, S., Reizis, B., Ravindran, R., Nakaya, H., Salazar-Gonzalez, R. M., Wang, Y. C., and Pulendran, B. (2010). Activation of beta-catenin in dendritic cells regulates immunity versus tolerance in the intestine. Science 329, 849-853.

Maynard, C. L., Harrington, L. E., Janowski, K. M., Oliver, J. R., Zindl, C. L., Rudensky, A. Y., and Weaver, C. T. (2007). Regulatory T cells expressing interleukin 10 develop from Foxp3+ and Foxp3- precursor cells in the absence of interleukin 10 . Nat. Immunol. 8, 931-941. 
Maynard, C. L., Hatton, R. D., Helms, W. S., Oliver, J. R., Stephensen, C. B., and Weaver, C. T. (2009). Contrasting roles for all-trans retinoic acid in TGF-beta-mediated induction of Foxp3 and Il10 genes in developing regulatory T cells. J. Exp. Med. 206, 343-357.

McIlroy, D., Troadec, C., Grassi, F., Samri, A., Barrou, B., Autran, B., Debre, P., Feuillard, J., and Hosmalin, A. (2001). Investigation of human spleen dendritic cell phenotype and distribution reveals evidence of in vivo activation in a subset of organ donors. Blood 97, 3470-3477.

Meiler, F., Zumkehr, J., Klunker, S., Ruckert, B., Akdis, C. A., and Akdis, M. (2008). In vivo switch to IL-10secreting $\mathrm{T}$ regulatory cells in high dose allergen exposure. J. Exp. Med. 205, 2887-2898.

Menges, M., Rossner, S., Voigtlander, C., Schindler, H., Kukutsch, N. A., Bogdan, C., Erb, K., Schuler, G., and Lutz, M.B. (2002). Repetitive injections of dendritic cells matured with tumor necrosis factor alpha induce antigen-specific protection of mice from autoimmunity. J. Exp. Med. 195, 15-21.

Misra, N., Bayry, J., Lacroix-Desmazes, S., Kazatchkine, M. D., and Kaveri, S. V. (2004). Cutting edge: human $\mathrm{CD} 4+\mathrm{CD} 25+\mathrm{T}$ cells restrain the maturation and antigen-presenting function of dendritic cells. $J$. Immunol. 172, 4676-4680.

Miyara, M., and Sakaguchi, S. (2007). Natural regulatory $\mathrm{T}$ cells: mechanisms of suppression. Trends Mol. Med. 13, 108-116.

Monteleone, I., Platt, A. M., Jaensson, E., Agace, W. W., and Mowat, A. M. (2008). IL-10-dependent partial refractoriness to Toll-like receptor stimulation modulates gut mucosal dendritic cell function. Eur. J. Immunol. 38, 1533-1547.

Moore, K. W., De Waal Malefyt, R., Coffman, R. L., and O'garra, A. (2001). Interleukin-10 and the interleukin10 receptor. Annu. Rev. Immunol. 19, 683-765.

Motomura, Y., Kitamura, H., Hijikata, A., Matsunaga, Y., Matsumoto, K., Inoue, H., Atarashi, K., Hori, S., Watarai, H., Zhu, J., Taniguchi, M., and Kubo, M. (2011). The transcription factor E4BP4 regulates the production of IL-10 and IL-13 in CD4(+) T cells. Nat. Immunol. 12, 450-459.

Niesner, U., Albrecht, I., Janke, M., Doebis, C., Loddenkemper, C., Lexberg, M. H., Eulenburg, K., Kreher, S., Koeck, J., Baumgrass, R., Bonhagen, K., Kamradt, T., Enghard, P.,
Humrich, J. Y., Rutz, S., SchulzeTopphoff, U., Aktas, O., Bartfeld, S. Radbruch, H., Hegazy, A. N., Lohning, M., Baumgart, D. C., Duchmann, R., Rudwaleit, M., Haupl, T., Gitelman, I., Krenn, V., Gruen, J., Sieper, J., Zeitz, M., Wiedenmann, B., Zipp, F., Hamann, A., Janitz, M., Scheffold, A., Burmester, G. R., Chang, H. D., and Radbruch, A. (2008). Autoregulation of Th1mediated inflammation by twist1. J. Exp. Med. 205, 1889-1901.

Noval Rivas, M., Weatherly, K., Hazzan, M., Vokaer, B., Dremier, S., Gaudray, F., Goldman, M., Salmon, I., and Braun, M. Y. (2009). Reviving function in CD4+ T cells adapted to persistent systemic antigen. J. Immunol. $183,4284-4291$

O'Garra, A., Vieira, P. L., Vieira, P., and Goldfeld, A. E. (2004). IL10 -producing and naturally occurring CD4+ Tregs: limiting collateral damage. J. Clin. Invest. 114, 1372-1378.

Ohkura, N., and Sakaguchi, S. (2010). Regulatory $\mathrm{T}$ cells: roles of $\mathrm{T}$ cell receptor for their development and function. Semin. Immunopathol. 32, 95-106.

Okamura, T., Fujio, K., Shibuya, M., Sumitomo, S., Shoda, H., Sakaguchi, S., and Yamamoto, K. (2009). CD4+CD25-LAG3+ regulatory $\mathrm{T}$ cells controlled by the transcription factor Egr-2. Proc. Natl. Acad. Sci. U.S.A. 106, 13974-13979.

Oldenhove, G., De Heusch, M., UrbainVansanten, G., Urbain, J., Maliszewski, C., Leo, O., and Moser, M. (2003). CD4+ CD25+ regulatory $\mathrm{T}$ cells control $\mathrm{T}$ helper cell type 1 responses to foreign antigens induced by mature dendritic cells in vivo. J. Exp. Med. 198, 259-266.

Onishi, Y., Fehervari, Z., Yamaguchi, T., and Sakaguchi, S. (2008). Foxp3+ natural regulatory $\mathrm{T}$ cells preferentially form aggregates on dendritic cells in vitro and actively inhibit their maturation. Proc. Natl. Acad. Sci. U.S.A. 105, 10113-10118.

O'Shea, J. J., and Paul, W. E. (2010). Mechanisms underlying lineage commitment and plasticity of helper CD4+ T cells. Science 327, 1098-1102.

Pacholczyk, R., Ignatowicz, H., Kraj, P., and Ignatowicz, L. (2006). Origin and $\mathrm{T}$ cell receptor diversity of Foxp3+CD4+CD25+ $\mathrm{T}$ cells. Immunity 25, 249-259.

Pasare, C., and Medzhitov, R. (2003). Toll pathway-dependent blockade of $\mathrm{CD} 4+\mathrm{CD} 25+\mathrm{T}$ cell-mediated suppression by dendritic cells. Science 299, 1033-1036.
Paust, S., Lu, L., Mccarty, N., and Cantor, H. (2004). Engagement of B7 on effector $\mathrm{T}$ cells by regulatory $\mathrm{T}$ cells prevents autoimmune disease. Proc. Natl. Acad. Sci. U.S.A. 101, 10398-10403.

Péguet-Navarro, J., Moulon, C., Caux, C., Dalbiez-Gauthier, C., Banchereau, J., and Schmitt, D. (1994). Interleukin-10 inhibits the primary allogeneic $\mathrm{T}$ cell response to human epidermal Langerhans cells. Eur. J. Immunol. 24, 884-891.

Perez, N., Karumuthil-Melethil, S., Li, R., Prabhakar, B. S., Holterman, M. J., and Vasu, C. (2008). Preferential costimulation by CD80 results in IL-10-dependent TGF-betal(+)adaptive regulatory $\mathrm{T}$ cell generation. J. Immunol. 180, 6566-6576.

Perona-Wright, G., Jenkins, S. J., and Macdonald, A. S. (2006). Dendritic cell activation and function in response to Schistosoma mansoni. Int. J. Parasitol. 36, 711-721.

Piggott, D. A., Eisenbarth, S. C., Xu, L., Constant, S. L., Huleatt, J. W., Herrick, C. A., and Bottomly, K. (2005). MyD88-dependent induction of allergic Th2 responses to intranasal antigen. J. Clin. Invest. $115,459-467$.

Pot, C., Jin, H., Awasthi, A., Liu, S. M., Lai, C. Y., Madan, R., Sharpe, A. H., Karp, C. L., Miaw, S. C., Ho, I. C., and Kuchroo, V. K. (2009). Cutting edge: IL-27 induces the transcription factor c-Maf, cytokine IL21 , and the costimulatory receptor ICOS that coordinately act together to promote differentiation of IL-10producing $\operatorname{Tr} 1$ cells. J. Immunol. 183, 797-801.

Qureshi, O. S., Zheng, Y., Nakamura, K., Attridge, K., Manzotti, C., Schmidt, E. M., Baker, J., Jeffery, L. E., Kaur, S., Briggs, Z., Hou, T. Z., Futter, C. E., Anderson, G., Walker, L. S., and Sansom, D. M. (2011). Transendocytosis of CD80 and CD86: a molecular basis for the cell-extrinsic function of CTLA-4. Science 332, 600-603.

Riedl, E., Stockl, J., Majdic, O., Scheinecker, C., Knapp, W., and Strobl, H. (2000). Ligation of E-cadherin on in vitro-generated immature Langerhans-type dendritic cells inhibits their maturation. Blood 96, 4276-4284.

Roncarolo, M. G., Gregori, S., Battaglia, M., Bacchetta, R., Fleischhauer, K., and Levings, M. K. (2006). Interleukin-10-secreting type 1 regulatory $\mathrm{T}$ cells in rodents and humans. Immunol. Rev. 212, 28-50.

Round, J. L., and Mazmanian, S. K. (2010). Inducible Foxp3+ regulatory T-cell development by a commensal bacterium of the intestinal microbiota. Proc. Natl. Acad. Sci. U.S.A. 107, 12204-12209.

Rutz, S., Janke, M., Kassner, N., Hohnstein, T., Krueger, M., and Scheffold, A. (2008). Notch regulates IL10 production by $\mathrm{T}$ helper 1 cells. Proc. Natl. Acad. Sci. U.S.A. 105, 3497-3502.

Safford, M., Collins, S., Lutz, M. A., Allen, A., Huang, C. T., Kowalski, J., Blackford, A., Horton, M. R., Drake, C., Schwartz, R. H., and Powell, J. D. (2005). Egr- 2 and Egr- 3 are negative regulators of T cell activation. Nat. Immunol. 6, 472-480.

Sakaguchi, S., Yamaguchi, T., Nomura, T., and Ono, M. (2008). Regulatory $\mathrm{T}$ cells and immune tolerance. Cell 133, 775-787.

Salomon, B., Lenschow, D. J., Rhee, L., Ashourian, N., Singh, B., Sharpe, A., and Bluestone, J. A. (2000). B7/CD28 costimulation is essential for the homeostasis of the CD4+CD25+ immunoregulatory $\mathrm{T}$ cells that control autoimmune diabetes. Immunity 12, 431-440.

Sansom, D. M., and Walker, L. S. (2006). The role of $\mathrm{CD} 28$ and cytotoxic Tlymphocyte antigen-4 (CTLA-4) in regulatory T-cell biology. Immunol. Rev. 212, 131-148.

Saraiva, M., Christensen, J. R., Veldhoen, M., Murphy, T. L., Murphy, K. M., and O'garra, A. (2009). Interleukin10 production by Th1 cells requires interleukin-12-induced STAT4 transcription factor and ERK MAP kinase activation by high antigen dose. Immunity 31, 209-219.

Saraiva, M., and O'Garra, A. (2010). The regulation of IL-10 production by immune cells. Nat. Rev. Immunol. 10, 170-181.

Sato, K., Yamashita, N., and Matsuyama, T. (2002). Human peripheral blood monocyte-derived interleukin-10induced semi-mature dendritic cells induce anergic $\mathrm{CD} 4(+)$ and $\mathrm{CD} 8(+) \mathrm{T}$ cells via presentation of the internalized soluble antigen and cross-presentation of the phagocytosed necrotic cellular fragments. Cell. Immunol. 215, 186-194.

Semple, K., Nguyen, A., Yu, Y., Wang, H., Anasetti, C., and Yu, X. Z. (2011). Strong CD28 costimulation suppresses induction of regulatory $\mathrm{T}$ cells from naive precursors through Lck signaling. Blood 117, 3096-3103. Serra, P., Amrani, A., Yamanouchi, J., Han, B., Thiessen, S., Utsugi, T., Verdaguer, J., and Santamaria, P. (2003). CD40 ligation releases immature dendritic cells from the control of regulatory CD4+CD25+ T cells. Immunity 19 , 877-889. 
Setoguchi, R., Hori, S., Takahashi, T., and Sakaguchi, S. (2005). Homeostatic maintenance of natural Foxp3(+) CD25(+) CD4(+) regulatory $\mathrm{T}$ cells by interleukin (IL)-2 and induction of autoimmune disease by IL-2 neutralization. J. Exp. Med. 201, 723-735.

Shevach, E. M. (2009). Mechanisms of foxp $3+\mathrm{T}$ regulatory cell-mediated suppression. Immunity 30, 636-645.

Singh, N. J., and Schwartz, R. H. (2003). The strength of persistent antigenic stimulation modulates adaptive tolerance in peripheral CD4+ T cells. J. Exp. Med. 198, 1107-1117.

Sixt, M., Kanazawa, N., Selg, M., Samson, T., Roos, G., Reinhardt, D. P., Pabst, R., Lutz, M. B., and Sorokin, L. (2005). The conduit system transports soluble antigens from the afferent lymph to resident dendritic cells in the $\mathrm{T}$ cell area of the lymph node. Immunity 22, 19-29.

Soares, H., Waechter, H., Glaichenhaus, N., Mougneau, E., Yagita, H., Mizenina, O., Dudziak, D., Nussenzweig, M. C., and Steinman, R. M. (2007). A subset of dendritic cells induces $\mathrm{CD} 4+\mathrm{T}$ cells to produce IFNgamma by an IL-12-independent but CD70-dependent mechanism in vivo. J. Exp. Med. 204, 1095-1106.

Spörri, R., and Reis e Sousa, C. (2005). Inflammatory mediators are insufficient for full dendritic cell activation and promote expansion of CD4+ $\mathrm{T}$ cell populations lacking helper function. Nat. Immunol. 6, 163-170.

Stefanova, I., Hilgert, I., Kristofova, H., Brown, R., Low, M. G., and Horejsi, V. (1989). Characterization of a broadly expressed human leucocyte surface antigen MEM-43 anchored in membrane through phosphatidylinositol. Mol. Immunol. 26, 153-161.

Stijlemans, B., Guilliams, M., Raes, G., Beschin, A., Magez, S., and De Baetselier, P. (2007). African trypanosomosis: from immune escape and immunopathology to immune intervention. Vet. Parasitol. 148, 3-13.

Suffner, J., Hochweller, K., Kuhnle, M. C., Li, X., Kroczek, R. A., Garbi, N., and Hammerling, G. J. (2010). Dendritic cells support homeostatic expansion of Foxp3+ regulatory $\mathrm{T}$ cells in Foxp3.LuciDTR mice. J. Immunol. 184, 1810-1820.

Summers, K. L., Hock, B. D., Mckenzie, J. L., and Hart, D. N. (2001). Phenotypic characterization of five dendritic cell subsets in human tonsils. Am. J. Pathol. 159, 285-295.

Sun, C. M., Hall, J. A., Blank, R. B., Bouladoux, N., Oukka, M., Mora, J. R., and Belkaid, Y. (2007). Small intestine lamina propria dendritic cells promote de novo generation of Foxp3 T reg cells via retinoic acid. J. Exp. Med. 204, 1775-1785.

Sundstedt, A., O'neill, E. J., Nicolson, K. S., and Wraith, D. C. (2003). Role for IL-10 in suppression mediated by peptide-induced regulatory $\mathrm{T}$ cells in vivo. J. Immunol. 170, 1240-1248.

Suri-Payer, E., and Cantor, H. (2001). Differential cytokine requirements for regulation of autoimmune gastritis and colitis by $\mathrm{cd} 4(+) \mathrm{cd} 25(+) \mathrm{t}$ cells. J. Autoimmun. 16, 115-123.

Swee, L. K., Bosco, N., Malissen, B., Ceredig, R., and Rolink, A. (2009). Expansion of peripheral naturally occurring T regulatory cells by Fmslike tyrosine kinase 3 ligand treatment. Blood 113, 6277-6287.

Tadokoro, C. E., Shakhar, G., Shen, S., Ding, Y., Lino, A. C., Maraver, A., Lafaille, J. J., and Dustin, M. L. (2006). Regulatory T cells inhibit stable contacts between CD4+ $\mathrm{T}$ cells and dendritic cells in vivo. $J$. Exp. Med. 203, 505-511.

Tang, Q., Adams, J. Y., Tooley, A. J., Bi, M., Fife, B. T., Serra, P., Santamaria, P., Locksley, R. M., Krummel, M. F., and Bluestone, J. A. (2006). Visualizing regulatory $\mathrm{T}$ cell control of autoimmune responses in nonobese diabetic mice. Nat. Immunol. 7, 83-92.

Tang, Q., Boden, E. K., Henriksen, K. J., Bour-Jordan, H., Bi, M., and Bluestone, J. A. (2004). Distinct roles of CTLA-4 and TGFbeta in $\mathrm{CD} 4+\mathrm{CD} 25+$ regulatory $\mathrm{T}$ cell function. Eur. J. Immunol. 34, 2996-3005.

Tang, Q., Henriksen, K. J., Boden, E. K., Tooley, A. J., Ye, J., Subudhi, S. K., Zheng, X. X., Strom, T. B., and Bluestone, J. A. (2003). Cutting edge: CD28 controls peripheral homeostasis of CD4+CD25+ regulatory T cells. J. Immunol. 171, 3348-3352.

Tarbell, K. V., Yamazaki, S., and Steinman, R. M. (2006). The interactions of dendritic cells with antigen-specific, regulatory $\mathrm{T}$ cells that suppress autoimmunity. Semin. Immunol. 18, 93-102.

Thorstenson, K. M., and Khoruts, A. (2001). Generation of anergic and potentially immunoregulatory CD25+CD4 $\mathrm{T}$ cells in vivo after induction of peripheral tolerance with intravenous or oral antigen. $J$. Immunol. 167, 188-195.

Valencia, X., Stephens, G., GoldbachMansky, R., Wilson, M., Shevach, E. M., and Lipsky, P. E. (2006). TNF downmodulates the function of human CD4+CD25hi T-regulatory cells. Blood 108, 253-261. van der Aar, A. M., Sibiryak, D. S., Bakdash, G., Van Capel, T. M., Van Der Kleij, H. P., Opstelten, D. J., Teunissen, M. B., Kapsenberg, M. L., and De Jong, E. C. (2011). Vitamin D3 targets epidermal and dermal dendritic cells for induction of distinct regulatory T cells. J. Allergy Clin. Immunol. 127, 1532.e7-1540.e7.

Vandenabeele, S., Hochrein, H., Mavaddat, N., Winkel, K., and Shortman, K. (2001). Human thymus contains 2 distinct dendritic cell populations. Blood 97, 1733-1741.

Veldhoen, M., Moncrieffe, H., Hocking, R. J., Atkins, C. J., and Stockinger, B. (2006). Modulation of dendritic cell function by naive and regulatory CD4+ T cells. J. Immunol. 176, 6202-6210.

Verbovetski, I., Bychkov, H., Trahtemberg, U., Shapira, I., Hareuveni, M., Ben-Tal, O., Kutikov, I., Gill, O., and Mevorach, D. (2002). Opsonization of apoptotic cells by autologous iC3b facilitates clearance by immature dendritic cells, down-regulates DR and CD86, and up-regulates CC chemokine receptor 7. J. Exp. Med. 196, 1553-1561.

Verginis, P., Li, H. S., and Carayanniotis, G. (2005). Tolerogenic semimature dendritic cells suppress experimental autoimmune thyroiditis by activation of thyroglobulin-specific CD4+CD25+ T cells. J. Immunol. 174, 7433-7439.

Vieira, P. L., Christensen, J. R., Minaee, S., O'neill, E. J., Barrat, F. J., Boonstra, A., Barthlott, T., Stockinger, B., Wraith, D. C., and O'garra, A. (2004). IL-10-secreting regulatory $T$ cells do not express Foxp3 but have comparable regulatory function to naturally occurring $\mathrm{CD} 4+\mathrm{CD} 25+$ regulatory $\mathrm{T}$ cells. J. Immunol. 172, 5986-5993.

Vuitton, D. A., and Gottstein, B. (2010). Echinococcus multilocularis and its intermediate host: a model of parasite-host interplay. J. Biomed. Biotechnol. 2010, 923193.

Wakkach, A., Cottrez, F., and Groux, H. (2001). Differentiation of regulatory $\mathrm{T}$ cells 1 is induced by CD2 costimulation. J. Immunol. 167, 3107-3113.

Wan, S., Xia, C., and Morel, L. (2007). IL-6 produced by dendritic cells from lupus-prone mice inhibits CD4+CD25+ T cell regulatory functions. J. Immunol. 178, 271-279.

Wang, L., Pino-Lagos, K., De Vries, V. C., Guleria, I., Sayegh, M. H., and Noelle, R. J. (2008). Programmed death 1 ligand signaling regulates the generation of adaptive Foxp3+CD4+ regulatory $\mathrm{T}$ cells.
Proc. Natl. Acad. Sci. U.S.A. 105, 9331-9336.

Wang, R. F. (2008). CD8+ regulatory $\mathrm{T}$ cells, their suppressive mechanisms, and regulation in cancer. Hum. Immunol. 69, 811-814.

Weiner, H. L., Da Cunha, A. P., Quintana, F., and Wu, H. (2011). Oral tolerance. Immunol. Rev. 241, 241-259.

Wiethe, C., Debus, A., Mohrs, M., Steinkasserer, A., Lutz, M., and Gessner, A. (2008). Dendritic cell differentiation state and their interaction with NKT cells determine Th1/Th2 differentiation in the murine model of Leishmania major infection. J. Immunol. 180, 4371-4381.

Wiethe, C., Schiemann, M., Busch, D. Haeberle, L., Kopf, M., Schuler, G., and Lutz, M. B. (2007). Interdependency of MHC class II/self-peptide and CD1d/self-glycolipid presentation by TNF-matured dendritic cells for protection from autoimmunity. J. Immunol. 178, 4908-4916.

Wing, K., Onishi, Y., Prieto-Martin, P., Yamaguchi, T., Miyara, M., Fehervari, Z., Nomura, T., and Sakaguchi, S. (2008). CTLA-4 control over Foxp3 + regulatory T cell function. Science 322, 271-275.

Witsch, E. J., Peiser, M., Hutloff, A., Buchner, K., Dorner, B. G., Jonuleit, H., Mages, H. W., and Kroczek, R. A. (2002). ICOS and CD28 reversely regulate IL-10 on re-activation of human effector $\mathrm{T}$ cells with mature dendritic cells. Eur. J. Immunol. 32, 2680-2686.

Wong, J., Obst, R., Correia-Neves, M. Losyev, G., Mathis, D., and Benoist, C. (2007). Adaptation of TCR repertoires to self-peptides in regulatory and nonregulatory CD4+ T cells. $J$. Immunol. 178, 7032-7041.

Worbs, T., Bode, U., Yan, S., Hoffmann, M. W., Hintzen, G., Bernhardt, G., Forster, R., and Pabst, O. (2006). Oral tolerance originates in the intestinal immune system and relies on antigen carriage by dendritic cells. J. Exp. Med. 203, 519-527.

Xu, X., Guo, Z., Jiang, X., Yao, Y., Gao, Q., Ding, Y., and Cao, X. (2011). Regulatory dendritic cells program generation of interleukin-4-producing alternative memory CD4 $\mathrm{T}$ cells with suppressive activity. Blood 117, 1218-1227.

Yamazaki, S., Bonito, A. J., Spisek, R., Dhodapkar, M., Inaba, K., and Steinman, R. M. (2007). Dendritic cells are specialized accessory cells along with TGF-b for the differentiation of Foxp3+ CD $4+$ regulatory T cells from peripheral Foxp3- precursors. Blood 110, 4293-4302. 
Yamazaki, S., Dudziak, D., Heidkamp, G. F., Fiorese, C., Bonito, A. J., Inaba, K., Nussenzweig, M. C., and Steinman, R. M. (2008). CD8+ $\mathrm{CD} 205+$ splenic dendritic cells are specialized to induce Foxp3+ regulatory $\mathrm{T}$ cells. J. Immunol. 181, 6923-6933.

Yamazaki, S., Iyoda, T., Tarbell, K., Olson, K., Velinzon, K., Inaba, K., and Steinman, R. M. (2003). Direct expansion of functional CD25+ $\mathrm{CD} 4+$ regulatory $\mathrm{T}$ cells by antigenprocessing dendritic cells. J. Exp. Med. 198, 235-247.

Yamazaki, S., and Steinman, R. M. (2009). Dendritic cells as controllers of antigen-specific Foxp3+ regulatory T cells. J. Dermatol. Sci. 54, 69-75.

Yan, Z., Garg, S. K., and Banerjee, R. (2010). Regulatory T cells interfere with glutathione metabolism in dendritic cells and T cells. J. Biol. Chem. 285, 41525-41532.

Zeng, L., Wan, L., Chen, L., Li, S., Lu, Y., Huang, Q., Wang, L., Li, Y., Cheng, J., and Lu, X. (2006). Selective depletion of activated $\mathrm{T}$ cells by recombinant immunotoxin containing antiCTLA-4 single-chain fragment of variable antibody and N-terminal fragment of perforin. Transplant. Proc. 38, 2151-2153.

Zhou, Y., Kawasaki, H., Hsu, S. C., Lee, R. T., Yao, X., Plunkett, B., Fu, J.,
Yang, K., Lee, Y. C., and Huang, S. K. (2010). Oral tolerance to foodinduced systemic anaphylaxis mediated by the C-type lectin SIGNR1. Nat. Med. 16, 1128-1133.

Conflict of Interest Statement: The authors declare that the research was conducted in the absence of any commercial or financial relationships that could be construed as a potential conflict of interest.

Received: 10 June 2011; paper pending published: 24 June 2011; accepted: 18 August 2011; published online: 27 September 2011.
Citation: Pletinckx K, Döhler A, Pavlovic $V$ and Lutz MB (2011) Role of dendritic cell maturity/costimulation for generation, homeostasis, and suppressive activity of regulatory $T$ cells. Front. Immun. 2:39. doi: 10.3389/fimmu.2011.00039

This article was submitted to Frontiers in $T$ Cell Biology, a specialty of Frontiers in Immunology.

Copyright (c) 2011 Pletinckx, Döhler, Pavlovic and Lutz. This is an open-access article subject to a non-exclusive license between the authors and Frontiers Media $S A$, which permits use, distribution and reproduction in other forums, provided the original authors and source are credited and other Frontiers conditions are complied with. 